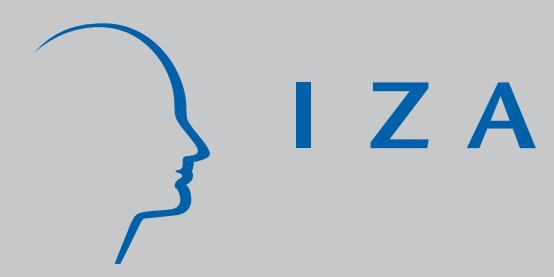

IZA DP No. 1755

Computer Skills, Destination Language Proficiency and the Earnings of Natives and Immigrants

Barry R. Chiswick

Paul W. Miller

September 2005 


\title{
Computer Skills, Destination Language Proficiency and the Earnings of Natives and Immigrants
}

\author{
Barry R. Chiswick \\ University of Illinois at Chicago \\ and IZA Bonn \\ Paul W. Miller \\ University of Western Australia \\ and IZA Bonn
}

Discussion Paper No. 1755

September 2005

\author{
IZA \\ P.O. Box 7240 \\ 53072 Bonn \\ Germany \\ Phone: +49-228-3894-0 \\ Fax: +49-228-3894-180 \\ Email: iza@iza.org
}

Any opinions expressed here are those of the author(s) and not those of the institute. Research disseminated by IZA may include views on policy, but the institute itself takes no institutional policy positions.

The Institute for the Study of Labor (IZA) in Bonn is a local and virtual international research center and a place of communication between science, politics and business. IZA is an independent nonprofit company supported by Deutsche Post World Net. The center is associated with the University of Bonn and offers a stimulating research environment through its research networks, research support, and visitors and doctoral programs. IZA engages in (i) original and internationally competitive research in all fields of labor economics, (ii) development of policy concepts, and (iii) dissemination of research results and concepts to the interested public.

IZA Discussion Papers often represent preliminary work and are circulated to encourage discussion. Citation of such a paper should account for its provisional character. A revised version may be available directly from the author. 


\title{
ABSTRACT
}

\section{Computer Skills, Destination Language Proficiency and the Earnings of Natives and Immigrants*}

\begin{abstract}
Using data from the 2001 Census of Population and Housing in Australia, this paper investigates the determinants, and consequences for earnings, of computer use by both the native born and the foreign born. Focussing on the foreign born, the multivariate analyses show that recent arrivals are more likely to use computers than the Australian born. As the level of computer use in Australia is much higher than in most of the countries that Australia's immigrants come from, this evidence suggests a high degree of favorable selection in migration. Study of the links between earnings, computer use and other human capital skills shows that educational attainment and destination language skills are complements to computer use. The use of a computer is shown to be a way the foreign born can increase the international transferability of their pre-immigration skills, a finding that has implications for immigrant settlement policies.
\end{abstract}

JEL Classification: F22, D13, J15, J24, J31, J61

Keywords: computers, internet, immigrants, language, earnings

Corresponding author:

Barry R. Chiswick

Department of Economics (M/C 144)

University of Illinois at Chicago

601 South Morgan Street (2103 UH)

Chicago, IL 60607-7121

USA

Email: brchis@uic.edu

\footnotetext{
* We thank Derby Voon for research assistance. Chiswick acknowledges research support from the Institute of Government and Public Affairs, University of Illinois. Miller acknowledges financial assistance from the Australian Research Council.
} 


\section{Computer Skills, Destination Language Proficiency and the Earnings of Natives and Immigrants}

\section{Introduction}

The impact that computer use has on wages has been examined for a number of countries. Krueger (1993) and Goss and Phillips (2002) conducted analyses for the US, Daldy and Gibson (2002) for New Zealand, Miller and Mulvey (1997a) for Australia, Dolton and Makepeace (2004) for the UK, Liu, Tsou and Hammitt (2004) for Taiwan and DiNardo and Pischke (1997) for Germany. These studies have addressed a number of research questions. Krueger (1993), for example, was interested in the extent to which computer use was associated with change to the wage structure. If use of computers complements other skills, then its increase is likely to lead to a widening of earnings differentials based on skill, whereas if it is a substitute for these other skills its increase is likely to lead to a compression of skill-based wage differentials. Hildreth's (2001) focus was on whether the wage premium to computer use (in his case e-mail) derived from the workplace encouraging worker productivity. Goss and Phillips (2002) investigated whether the wage differential associated with computer use resulted from differences in technology usage across industries or from differences in technology skills across individuals.

Two groups of workers that may differ in their technology skills are the native born and immigrants. The model of immigrant labor market adjustment proposed by Chiswick (1978) attaches considerable importance to the favorable selectivity of economic immigrants. ${ }^{1}$ This selectivity has been shown in analyses of the labor market outcomes of immigrants in many countries, and across different time periods, to be associated with more rapid growth in earnings for immigrants than for the native born. Part of this more rapid growth in earnings has been shown to derive from immigrants' post-migration investments in destination specific human capital, such as language skills, that are complementary to other forms of human capital, including that acquired in the

\footnotetext{
${ }^{1}$ This favorable selectivity may result from the favorable self-selectivity on the part of the migrants and/or selectivity in the immigration selection process.
} 
country of origin (Chiswick and Miller (2003)). A more intense use of computers, which might also be associated with the favorable selectivity of immigrants, could be another factor that gives rise to the immigrant post-migration adjustment phenomenon.

This paper examines the determinants of computer usage, with a special emphasis on the differences between immigrants and the native born, and also whether there are differences in the impact of computer usage on the earnings of these two groups. In doing this it looks at the inter-relationships among wages, computer skills and the other skills noted above as being quite important to the labor market success of immigrants, such as their educational attainment and proficiency in the dominant language of the country of destination. Thus, it is able to consider whether dominant destination proficiency, in this application English, is needed for computer literacy. It also considers whether part of the considerable wage premium to official language skills (see in particular Chiswick and Miller (1995)) could be associated with better computer literacy among those with dominant language proficiency. ${ }^{2}$ These analyses are conducted using data from the recent (2001) Census of Population and Housing in Australia.

The paper is structured as follows. Section II outlines the conceptual framework for the study of the incidence of computer/internet use. Section III provides details on the data set used, and contains a number of cross-tabulations that illustrate the considerable variation in computer/internet use across adult males in Australia in 2001. Section IV presents and discusses estimates of models of the determinants of computer use for male workers in Australia in 2001. Analyses by nativity are also considered. Section V examines the links between the use of computers and earnings. Summary comments and policy implications are contained in Section VI.

\footnotetext{
2 The conceptual framework recognizes that it may be proficiency in the dominant language of the internet (English) that matters more than the official language of the destination country. However, as the empirical analyses are conducted for an Englishspeaking country, Australia, the relative importance of this distinction cannot be assessed.
} 


\section{Conceptual Framework}

The demand for computers is perhaps best modelled as the demand for a "public good” within the family. That is, the family unit can be viewed as making a decision over whether to purchase a computer. Once the computer has been purchased, all members of the family will be able to use it.

Each member of the family can be thought of as having a utility function defined on private consumption $\left(x_{i}\right)$ and the availability of a computer in the household (C), namely $u_{i}=u_{i}\left(x_{i}, C\right)$. In this framework, computers are viewed as a homogenous quantity. Their lumpy nature is also recognised.

Assuming that the price of private consumption is unity, the annualized total cost of a computer is $c c$, individual $i$ 's contribution to the cost of this computer is $c_{i}$, and that $y_{i}$ is the $i^{\text {th }}$ person's income, the constraints facing the household with $n$ members are:

$$
\begin{aligned}
& c_{i}+x_{i}=y_{i} \quad i=1, n \\
& c C=\sum_{i=1}^{n} c_{i}
\end{aligned}
$$

The maximum amount that individual $i$ would be prepared to pay to have a computer in the household is given by their reservation price, $\left(r_{i}\right)$, defined implicitly by:

$$
r \text { is such that } u_{i}\left(x_{i}-r_{i}, 1\right)-u_{i}\left(x_{i}, 0\right)=0 \text {. }
$$

Provided that $\sum_{i=1}^{n} r_{i}>c c$ then the family should purchase a computer, and determine a way of funding the purchase such that $r_{i} \geq\left(y_{i}-x_{i}\right)$ for all family members. This will lead to a Pareto preferred allocation.

Hence, in this approach the demand for computers will depend on the strength of the preferences for computers for each member of the family. This will be a function of characteristics such as each individual's age, educational attainment and birthplace. These characteristics will impact on the individual's computer literacy and their benefit from the use of computers. The demand for computers will also presumably depend on the uses to which a computer can be put: for leisure, learning, household accounting, electronic purchases of goods, working at home, either during normal working hours 
(telecommuting) or off-hours, etc. This will be a function of a range of factors. Within a given country and for a given time period, one of the most important will be the degree of congruence between the individual's mother tongue and the language of the internet (primarily English for Australia).

The demand for computers will also depend on the distribution of income/wealth within the family, or equivalently, the extent to which individuals contribute to the cost of the family's public goods. Hence, even though a person living with the family may have intense preferences towards computers, this may not translate into a greater demand for the computer if this individual does not contribute towards the cost of the computer. Finally, although not part of the standard public good framework, the demand for computers will depend upon the degree of paternalism that those with resources $\left(y_{i}>0\right)$ exercise towards those without resources $\left(y_{i}=0\right)$. This is especially the case with parents caring for the welfare of their children.

Thus, according to this conceptual framework, the demand for computers by individual $i\left(D c_{i}\right)$ depends on:

$$
\begin{aligned}
D c_{i}= & f \text { (own characteristics, partner's characteristics, paternalism towards } \\
& \text { children, family characteristics). }
\end{aligned}
$$

The own characteristics that shape preferences towards computers which should be important are those that have been recognized in past studies (e.g. Liu et al. (2004), Miller and Mulvey (1997b), Dinardo and Pischke (1997)). These include age, educational attainment and gender. This list is extended in the current study to include birthplace, duration of residence of the foreign born and dominant language skills. The family's wealth will also affect the demand for computers, as will the distribution of this wealth within the family. Size of house and number of automobiles serve as proxies for family wealth.

Symmetry suggests that the partner's (spouse's) characteristics that impact on the demand by a family for a computer are the same as those included in the list of the individual's characteristics. However, as many of these will overlap those of the individual (e.g. birthplace, duration of residence, age in many instances) only a selection of partner's characteristics will be considered. Indeed, the preliminary analysis was based 
on the inclusion in the estimating equation of the partner's age and educational attainment. However, there is a high correlation between the ages of partners in the sample (over .9) and both the individual's age and that of their partner could not be included in the estimating equation.

The degree of parents' paternalism towards their children will presumably depend on (or alternatively can be measured by) a range of factors, including the type of school (private or government) attended, and the age of children. These details are cumbersome to include in an empirical model, especially where some families have many children. Hence only a summary measure provided by the number of dependent children present in the household is considered for inclusion in the models examined below.

Finally, information on non-dependent children and other relatives living in the family is included in the model. Where such individuals contribute to the cost of a computer (or other family public goods) it would be expected that this would increase the likelihood of the family owning a computer. However, where these individuals free-ride on the benevolence of the household head, and their behavior extends to other consumption items, then their presence would increase the demands placed on the primary family’s income and decrease the likelihood of the family owning a computer.

The impact of non-dependent children and other relatives on home computer use is expected to be less than that of dependent children. Part of the family investment in the human capital of children involves enhancing skills in new technology through home investments. This is why, in generations past, parents purchased encyclopedias for the home, and anecdotal evidence suggests it is a major motivating factor for home computer purchases in the current era.

\section{Data}

This study is based on the data from the 2001 Australian Census Household Sample File (HSF). The data were collected on Census night, August 7, 2001, and comprise a 1 percent sample of private dwellings, with their associated family and persons records, and a 1 percent sample of persons from all non-private dwellings together with a record for the non-private dwelling. These data are made available to researchers in the form of two versions of Confidentialized Unit Record Files (CURF): 
Basic and Expanded. Basic CURF contains less detailed data that are available for analysis on CD-ROM or accessed through the Remote Access Data Laboratory (RADL). ${ }^{3}$ The Expanded CURF has more detailed data, is available only through the RADL, and is used in the analyses presented below.

The Census CURFs contain many variables that are relevant to labor market research, including individual's weekly income, labor force status, hours worked, birthplace, computer use and English language skills. The variables used in this study are defined in Appendix D.

There are two questions that are relevant to computer usage, namely computer use at home and internet use. Computer use at home last week is coded as: 'No', 'Yes', 'Not stated', and 'Overseas visitor', whereas the internet use last week is coded as: 'No', 'Yes, at home', 'Yes, at work', 'Yes, elsewhere', 'Yes, at home and at work', 'Yes, at home and elsewhere', 'Yes, at work and elsewhere', 'Yes, at home, at work and elsewhere', 'Not stated', 'Overseas visitor'.

The information on English language skills comprise responses to questions on proficiency in English and languages spoken at home. Seven possible response categories are used for the proficiency in spoken English: 'Very well', 'Well', 'Not well', 'Not at all', 'Not stated', 'Not applicable (i.e., English Only)', 'Overseas visitor'. ${ }^{4}$ Forty one codes are used for the languages spoken at home in the Expanded CURF (see Appendix A for the listing of the languages spoken at home). ${ }^{5}$

This paper focuses only on males between the ages of 20-64 years old. This choice follows much of the literature on earnings determination, and is guided by the greater difficulties associated with obtaining measures of labor market experience among females, and the low rates of participation in the paid labor market among older and

\footnotetext{
${ }^{3}$ The RADL is an on-line database query system, under which microdata are held on a server at the Australian Bureau of Statistics (ABS) in Canberra. Registered users are able to submit programs (e.g. SAS, SPSS) to interrogate, analyze, model, etc. the data.

${ }^{4}$ The codes are different in the Basic CURF as compared to the Expanded CURF. Generally, most of the variables are coded in a less detailed manner in the Basic CURF.

${ }^{5}$ The variable for language spoken at home is coded using only 12 categories in the basic CURF.
} 
younger males. These low rates of participation in the paid labor force have the potential to generate substantial sample selection biases.

Table 1 presents the percentage recording computer use at home and internet use, whether at home or elsewhere, by birthplace of the individual. Across all birthplace groups (including Australia), 48 percent of males aged 20-64 use computers, and 48 percent use the internet. The variation in the incidence of use of computers and the internet across birthplace groups ranges from 23 percent for internet use among those born in South East Europe, to 72 percent for internet use among those born in Japan and Korea. The percentages for computer use at home and internet use are quite close for each of the birthplace groups, hence the discussion here will focus only on computer use. ${ }^{6}$ Individuals born in the Other English Speaking Developed countries, Africa, China, South and Central Asia, Japan and Korea have the highest percentages of computer users (58 percent to 67 percent). Countries of birth groups which have medium percentages using computers include Australia, New Zealand, Europe, South East Asia, Pacific Islands and Latin America. Those born in the Middle East and North Africa countries and South East Europe have the lowest percentages using computers.

The variations in the incidence of internet use across foreign birthplace groups in Australia may reflect the technological cultures of the countries of origin. To assess this, the data on internet use in Table 1 for the foreign birthplace groups in Australia were correlated with data on the incidence of computer use in the countries of origin. ${ }^{7}$ The simple correlation coefficient, however, was not significantly different from zero, even when the data are limited to those in Australia five or fewer years. In other words, there appears to be no relation between computer use in Australia and the extent of computer use in the country of origin. With the exception of those born in English-speaking developed countries, the extent of internet use is much greater among immigrants in

\footnotetext{
${ }^{6}$ The simple correlation coefficient between these birthplace proportions is 0.99 , which indicates that for the birthplace categories included in Table 1 both computer use and internet use are very highly correlated. At the level of the individual, a simple crosstabulation of computer use by internet use shows that 85.3 percent of adult males were in the same classification (user or non-user) for computer use as they were for internet use.

7 These data were extracted from the CIA World Factbook 2003. The relevant comparison data are presented in Appendix C.
} 
Australia than is the incidence in their countries of origin (compare Table 1 and Appendix C). This suggests favorable selectivity in migration.

\section{Table 1}

Computer/Internet Use By Birthplace, Adult Males, 2001 ${ }^{\text {(a) }}$

\begin{tabular}{lccc}
\hline \multicolumn{1}{c}{ Birthplace } & \% of Sample & Computer Use (\%) & Internet Use (\%) \\
\hline \hline Australia & 72.07 & 46.77 & 46.78 \\
New Zealand & 2.69 & 51.25 & 52.14 \\
Other English Speaking & 8.57 & 57.55 & 58.40 \\
Developed Countries & & & \\
Europe (except South & 4.32 & 42.62 & 40.94 \\
Eastern Europe, United & & & \\
Kingdom and Ireland) & & & \\
South Eastern Europe & 2.31 & 26.14 & 63.41 \\
Africa & 0.49 & 66.93 & 32.87 \\
Middle East and North & 1.82 & 32.77 & \\
Africa & & & 48.29 \\
South East Asia & 3.17 & 50.85 & 59.77 \\
China & 1.48 & 61.87 & 67.36 \\
Southern and Central & 1.49 & 64.13 & 40.50 \\
Asia & & & 71.50 \\
Pacific Islands & 0.61 & 40.63 & 48.40 \\
Japan and Korea & 0.39 & 66.67 & 47.61 \\
Latin America & 0.60 & 49.20 & \\
Total & 100.00 & 47.67 & \\
\hline Soure: & & & \\
\hline
\end{tabular}

Source: 2001 Census Household Sample File (HSF).

(a) The birthplaces have been grouped regionally; see Appendix B for detailed listing of countries comprising each regional group.

Table 2 shows the incidence of computer use at home and internet use by the language spoken at home and by proficiency in spoken English. These data are disaggregated by birthplace. Only the top 20 languages groups are reported in this table. These language groups comprise English and the languages spoken by around 77 percent of all non-English language speakers in Australia. 


\section{Table 2}

\begin{tabular}{|c|c|c|c|c|c|c|}
\hline & \multicolumn{3}{|c|}{ Computer Use (\%) } & \multicolumn{3}{|c|}{ Internet Use (\%) } \\
\hline & $\begin{array}{c}\text { Born in } \\
\text { Australia }\end{array}$ & $\begin{array}{c}\text { Born } \\
\text { Overseas } \\
\end{array}$ & Total & $\begin{array}{c}\text { Born in } \\
\text { Australia }\end{array}$ & $\begin{array}{c}\text { Born } \\
\text { Overseas }\end{array}$ & Total \\
\hline \multicolumn{7}{|l|}{ Language Spoken at Home } \\
\hline English & 46.83 & 55.30 & 48.38 & 46.90 & 55.62 & 48.50 \\
\hline Italian & 46.98 & 26.81 & 37.37 & 44.46 & 24.51 & 34.99 \\
\hline Greek & 49.28 & 19.86 & 35.47 & 50.83 & 16.28 & 34.57 \\
\hline Cantonese & 78.79 & 56.21 & 57.36 & 84.85 & 54.65 & 56.19 \\
\hline Arabic (incl. Lebanese) & 52.82 & 31.02 & 35.61 & 50.70 & 29.51 & 33.98 \\
\hline Vietnamese & $71.43^{(\mathrm{b})}$ & 32.17 & 33.27 & $46.67^{(\mathrm{b})}$ & 26.76 & 27.36 \\
\hline Mandarin & $72.73^{(b)}$ & 66.19 & 66.36 & $63.64^{(b)}$ & 65.65 & 65.60 \\
\hline Spanish & 68.57 & 46.24 & 48.73 & 79.41 & 45.52 & 49.20 \\
\hline Tagalog (Filipino) & $60.00^{(b)}$ & 59.22 & 59.24 & $60.00^{(b)}$ & 54.80 & 54.95 \\
\hline Macedonian & 54.43 & 19.65 & 30.56 & 53.16 & 15.29 & 27.31 \\
\hline Croatian & 49.23 & 15.28 & 25.84 & 47.69 & 15.38 & 25.48 \\
\hline German & 66.67 & 54.09 & 56.72 & 65.85 & 56.33 & 58.29 \\
\hline Polish & 37.04 & 53.91 & 50.97 & 40.74 & 45.67 & 44.81 \\
\hline Hindi & $33.33^{(\mathrm{b})}$ & 63.58 & 63.03 & $33.33^{(b)}$ & 67.28 & 66.67 \\
\hline Serbian & 57.69 & 28.91 & 33.77 & 57.69 & 26.77 & 32.03 \\
\hline Turkish & $61.11^{(b)}$ & 27.94 & 31.82 & $55.56^{(b)}$ & 27.41 & 30.72 \\
\hline Indonesian & $66.67^{(\mathrm{b})}$ & 74.42 & 73.61 & $86.67^{(b)}$ & 75.78 & 76.92 \\
\hline Korean & $50.00^{(b)}$ & 61.11 & 60.77 & $75.00^{(b)}$ & 65.87 & 66.15 \\
\hline French & $69.57^{(\mathrm{b})}$ & 64.55 & 65.41 & $56.52^{(b)}$ & 60.91 & 60.15 \\
\hline Maltese & 33.33 & 21.88 & 25.00 & 30.56 & 21.65 & 24.06 \\
\hline All Other Languages & 41.19 & 51.01 & 49.41 & 42.04 & 52.57 & 50.87 \\
\hline Total $^{(\mathrm{a})}$ & 46.97 & 50.11 & 47.85 & 47.01 & 49.86 & 47.81 \\
\hline \multicolumn{7}{|c|}{ Proficiency in Spoken English } \\
\hline $\begin{array}{l}\text { Only English Spoken at } \\
\text { Home }\end{array}$ & 46.83 & 55.30 & 48.38 & 46.90 & 55.62 & 48.50 \\
\hline \multicolumn{7}{|l|}{$\begin{array}{l}\text { Language other than } \\
\text { English Spoken at Home } \\
\text { and Speak English }\end{array}$} \\
\hline Very Well & 52.33 & 58.85 & 56.52 & 51.20 & 58.96 & 56.19 \\
\hline Well & 22.16 & 35.71 & 34.79 & 24.70 & 34.37 & 33.72 \\
\hline Not Well & 17.31 & 15.73 & 15.82 & 21.57 & 13.08 & 13.52 \\
\hline Not at All & $0.00^{(\mathrm{b})}$ & 7.07 & 6.14 & $6.67^{(\mathrm{b})}$ & 7.07 & 7.02 \\
\hline Total $^{(a)}$ & 46.93 & 50.08 & 47.81 & 46.96 & 49.89 & 47.78 \\
\hline
\end{tabular}

Source: 2001 Census Household Sample File (HSF).

Note: (a) Total may differ across Tables owing to missing values on the variable under consideration.

(b) Computation based on fewer than 25 observations. 
Individuals who speak Indonesian at home have the highest rates of using computers at home and of using the internet (74 percent and 77 percent, respectively). This is followed by those who speak Mandarin, with a rate of 66 percent for both computer use at home and internet use, and individuals who speak Hindi at home, with 67 percent using the internet. Individuals who speak Croatian at home are the least likely to use computers (26 percent) and the internet (25 percent).

The rates of using computers at home and the internet for individuals who have excellent proficiency in spoken English and those who have limited or no English skills differ greatly. As shown in Table 2, those who speak English very well have rates of 57 percent and 56 percent for using computers at home and for internet use, respectively, while those who cannot speak English have rates of only 6 percent (computer use at home) and 7 percent (internet use).

Hence this brief review of the data indicates considerable variation in the use of computers across birthplace groups, the related language groups and by proficiency in spoken English. The extent to which computer use varies with other characteristics is considered in the multivariate analyses that follow.

\section{Multivariate Analysis of the Incidence of Computer Use}

The multivariate analyses in the current section focus only on computer use from the 2001 Australian Census of Population and Housing. This is in order to facilitate comparisons with past studies, and because of the very high correlation between computer use at home and use of the internet - those with computers use the internet, and apparently those with a high demand for the internet use computers at home.

A logit model of the incidence of computer usage is estimated. This model can be expressed as:

$$
\operatorname{Prob}(\text { using computer })=\frac{1}{1+e^{-\beta x_{i}}}
$$

where $\beta$ is a vector of parameters to be estimated and $x_{i}$ is a vector of characteristics for the particular person. $\beta$ gives the impact of a particular variable on the log odds ratio.

The dependent variable for this logit analysis is a binary variable, set equal to one where the respondent used a computer at home in the week before Census night. A 
reasonably rich set of regressors is included in the model: Years of education, age (in quadratic form in the more general specification), English language proficiency (four dichotomous variables recording varying levels of proficiency for those who speak a language other than English at home, in comparison to those who speak only English at home), birthplace (either a single dichotomous variable for the foreign born or a set of eleven dichotomous regressors that record birthplace fixed effects in comparison with immigrants from New Zealand), labor market status (for the states of unemployed and not-in-the-labor force compared to the employed), marital status (whether married, spouse present), wealth status (proxied by the number of bedrooms in the respondent's house and by the number of cars at the dwelling), family structure (three variables), parents' birthplace (three variables for the Australian born) and the duration of residence of immigrants in Australia (a continuous variable). In computing the estimates of this model, individuals with missing information on Census variables used to construct the regressors have been excluded from the analysis. In addition, owing to the ambiguity of the interpretation of the family structure variables among those living in group households, the small proportion of individuals living in this category have also been excluded.

Table 3 lists estimates for four different versions of the logit model, namely models estimated: (i) for the sample pooled across the Australian born and the overseas born; (ii) for the Australian born; (iii) for the overseas born without birthplace fixed effects; and (iv) for the overseas born with birthplace fixed effects. These models are statistically significant as a whole, as indicated by the highly significant $\chi^{2}$ statistics. As well, most of the explanatory variables are significant in each of the separate models.

Table 3

Logit Models of Computer Use by Nativity, Adult Males, 2001 Australia Census of Population and Housing ${ }^{(a)}$

\begin{tabular}{|c|c|c|c|c|}
\hline Variables & Total Sample & $\begin{array}{l}\text { Australian } \\
\text { Born } \\
\\
\text { (ii) }\end{array}$ & $\begin{array}{l}\text { Overseas Born } \\
\text { (without } \\
\text { Birthplace Fixed } \\
\text { Effects) } \\
\text { (iii) }\end{array}$ & $\begin{array}{l}\text { Overseas Born } \\
\text { (with } \\
\text { Birthplace } \\
\text { Fixed effects) } \\
\text { (iv) } \\
\end{array}$ \\
\hline Constant & $\begin{array}{l}-4.803 \\
(28.35)\end{array}$ & $\begin{array}{c}-5.162 \\
(26.29)\end{array}$ & $\begin{array}{c}-2.878 \\
(15.26)\end{array}$ & $\begin{array}{c}-2.903 \\
(14.93)\end{array}$ \\
\hline
\end{tabular}




\begin{tabular}{|c|c|c|c|c|}
\hline Education & $\begin{array}{c}0.305 \\
(51.75)\end{array}$ & $\begin{array}{c}0.312 \\
(44.79)\end{array}$ & $\begin{array}{l}0.287 \\
(25.82)\end{array}$ & $\begin{array}{c}0.272 \\
(23.82)\end{array}$ \\
\hline Age & $\begin{array}{l}0.211 \\
(2.83)\end{array}$ & $\begin{array}{l}0.027 \\
(3.15)\end{array}$ & $\begin{array}{l}-0.020 \\
(8.29)\end{array}$ & $\begin{array}{l}-0.020 \\
(8.21)\end{array}$ \\
\hline Age squared/100 & $\begin{array}{l}-0.038 \\
(4.22)\end{array}$ & $\begin{array}{l}-0.041 \\
(3.90)\end{array}$ & (c) & (c) \\
\hline Married, spouse present & $\begin{array}{l}-0.551 \\
(6.61)\end{array}$ & $\begin{array}{l}-0.463 \\
(4.74)\end{array}$ & $\begin{array}{l}-0.818 \\
(5.07)\end{array}$ & $\begin{array}{l}-0.698 \\
(4.27)\end{array}$ \\
\hline $\begin{array}{l}\text { Education of Spouse where } \\
\text { spouse present }\end{array}$ & $\begin{array}{l}0.060 \\
(9.19)\end{array}$ & $\begin{array}{l}0.055 \\
(7.14)\end{array}$ & $\begin{array}{l}0.077 \\
(6.24)\end{array}$ & $\begin{array}{l}0.070 \\
(5.54)\end{array}$ \\
\hline $\begin{array}{l}\text { Number of dependent } \\
\text { children }\end{array}$ & $\begin{array}{l}0.110 \\
(8.99)\end{array}$ & $\begin{array}{l}0.130 \\
(9.18)\end{array}$ & $\begin{array}{l}0.052 \\
(2.20)\end{array}$ & $\begin{array}{l}0.083 \\
(3.42)\end{array}$ \\
\hline $\begin{array}{l}\text { Number of non-dependent } \\
\text { Children }\end{array}$ & $\begin{array}{l}-0.162 \\
(7.40)\end{array}$ & $\begin{array}{l}-0.147 \\
(5.71)\end{array}$ & $\begin{array}{l}-0.195 \\
(4.68)\end{array}$ & $\begin{array}{l}-0.182 \\
(4.29)\end{array}$ \\
\hline $\begin{array}{l}\text { Number of other related or } \\
\text { unrelated individuals }\end{array}$ & $\begin{array}{l}-0.185 \\
(5.93)\end{array}$ & $\begin{array}{l}-0.221 \\
(5.74)\end{array}$ & $\begin{array}{l}-0.115 \\
(2.09)\end{array}$ & $\begin{array}{l}-0.122 \\
(2.17)\end{array}$ \\
\hline Foreign Born & $\begin{array}{l}0.594 \\
(8.31)\end{array}$ & (c) & (c) & (c) \\
\hline Years Since Migration & $\begin{array}{l}-0.021 \\
(5.32)\end{array}$ & (c) & $\begin{array}{l}-0.013 \\
(3.08)\end{array}$ & $\begin{array}{l}-0.013 \\
(3.00)\end{array}$ \\
\hline \multicolumn{5}{|c|}{ English Skills (Speaks only English at Home) } \\
\hline Speak English Very Well & $\begin{array}{l}-0.089 \\
(2.11)\end{array}$ & $\begin{array}{l}0.027 \\
(0.38)\end{array}$ & $\begin{array}{l}-0.211 \\
(3.60)\end{array}$ & $\begin{array}{l}-0.094 \\
(1.23)\end{array}$ \\
\hline Speak English Well & $\begin{array}{l}-0.831 \\
(12.71)\end{array}$ & $\begin{array}{l}-0.748 \\
(3.07)\end{array}$ & $\begin{array}{c}-0.842 \\
(12.12)\end{array}$ & $\begin{array}{l}-0.862 \\
(9.37)\end{array}$ \\
\hline Speak English Not Well & $\begin{array}{c}-1.632 \\
(12.89)\end{array}$ & $\begin{array}{l}-0.677 \\
(1.48)\end{array}$ & $\begin{array}{l}-1.650 \\
(12.41)\end{array}$ & $\begin{array}{l}-1.866 \\
(12.02)\end{array}$ \\
\hline Speak English Not at All & $\begin{array}{l}-1.855 \\
(4.06)\end{array}$ & $\begin{array}{l}-9.468 \\
(0.09)\end{array}$ & $\begin{array}{l}-1.762 \\
(3.85)\end{array}$ & $\begin{array}{l}-2.130 \\
(4.45)\end{array}$ \\
\hline Unemployed & $\begin{array}{l}-0.068 \\
(1.36)\end{array}$ & $\begin{array}{l}-0.063 \\
(1.07)\end{array}$ & $\begin{array}{l}-0.088 \\
(0.95)\end{array}$ & $\begin{array}{l}-0.046 \\
(0.49)\end{array}$ \\
\hline Not in Labor Force & $\begin{array}{l}-0.087 \\
(2.31)\end{array}$ & $\begin{array}{l}-0.072 \\
(1.61)\end{array}$ & $\begin{array}{l}-0.140 \\
(2.13)\end{array}$ & $\begin{array}{l}-0.122 \\
(1.81)\end{array}$ \\
\hline Number of Bedrooms & $\begin{array}{c}0.182 \\
(11.95)\end{array}$ & $\begin{array}{c}0.192 \\
(10.80)\end{array}$ & $\begin{array}{l}0.150 \\
(5.11)\end{array}$ & $\begin{array}{l}0.136 \\
(4.58)\end{array}$ \\
\hline Number of Vehicles & $\begin{array}{c}0.146 \\
(10.20)\end{array}$ & $\begin{array}{l}0.144 \\
(8.76)\end{array}$ & $\begin{array}{l}0.161 \\
(5.46)\end{array}$ & $\begin{array}{l}0.173 \\
(5.80)\end{array}$ \\
\hline Both Parents Foreign Born & (c) & $\begin{array}{l}-0.323 \\
(3.58)\end{array}$ & (c) & (c) \\
\hline Only Father Foreign Born & (c) & $\begin{array}{l}0.160 \\
(2.50)\end{array}$ & (c) & (c) \\
\hline Only Mother Foreign Born & (c) & $\begin{array}{l}0.195 \\
(3.97)\end{array}$ & (c) & (c) \\
\hline \multicolumn{5}{|l|}{ Birthplace (New Zealand) ${ }^{(\mathrm{b})}$} \\
\hline Other English Speaking & (c) & (c) & (c) & 0.273 \\
\hline
\end{tabular}




\begin{tabular}{|c|c|c|c|c|}
\hline Developed Countries & & & & (3.36) \\
\hline $\begin{array}{l}\text { Europe (except South } \\
\text { Eastern Europe and United } \\
\text { Kingdom and Ireland) }\end{array}$ & (c) & (c) & (c) & $\begin{array}{l}0.198 \\
(1.98)\end{array}$ \\
\hline South Eastern Europe & (c) & (c) & (c) & $\begin{array}{l}-0.305 \\
(2.41)\end{array}$ \\
\hline Africa & (c) & (c) & (c) & $\begin{array}{l}0.697 \\
(3.41)\end{array}$ \\
\hline $\begin{array}{l}\text { Middle East and North } \\
\text { Africa }\end{array}$ & (c) & (c) & (c) & $\begin{array}{l}-0.500 \\
(3.74)\end{array}$ \\
\hline South East Asia & (c) & (c) & (c) & $\begin{array}{l}0.272 \\
(2.32)\end{array}$ \\
\hline China & (c) & (c) & (c) & $\begin{array}{l}0.920 \\
(6.06)\end{array}$ \\
\hline Southern and Central Asia & (c) & (c) & (c) & $\begin{array}{l}0.277 \\
(2.07)\end{array}$ \\
\hline Pacific Islands & (c) & (c) & (c) & $\begin{array}{l}-0.571 \\
(3.36)\end{array}$ \\
\hline Japan and Korea & (c) & (c) & (c) & $\begin{array}{l}1.031 \\
(4.21)\end{array}$ \\
\hline Latin America & (c) & (c) & (c) & $\begin{array}{r}0.340 \\
(1.92)\end{array}$ \\
\hline$\chi^{2}$ & 7605.74 & 4950.19 & 2727.02 & 2908.49 \\
\hline McFadden $R^{2}$ & 0.144 & 0.128 & 0.192 & 0.205 \\
\hline Prediction Success & 67.6 & 66.7 & 70.0 & 71.1 \\
\hline Sample Size & 38,044 & 27,817 & 10,227 & 10,227 \\
\hline
\end{tabular}

Source: 2001 Census Household Sample File (HSF).

Notes: (a) Asymptotic 't' statistics in parentheses.

(b) The birthplaces have been grouped regionally; see Appendix B for detailed listing of countries comprising each regional group.

(c) Variable not included.

Education level is found to have a positive impact on the probability of computer use, with the partial effect showing that an extra year of education increases the probability of computer use by 7 to 8 percentage points. ${ }^{8}$ This implies a complementary relationship in using these two skills. Moreover, this complementary relationship is

${ }^{8}$ The partial effect for a variable in the logit model can be calculated by the formula: $\frac{\partial \rho}{\partial x}=\rho(1-\rho) \hat{\beta}$, where $\rho$ is the probability of computer use in the data set for each particular model and $\hat{\beta}$ is the estimated coefficient for the variable $x$. The partial effects discussed in the text have been computed at the sample mean value of $\rho$. 
remarkably similar for the Australian born and for the overseas born. The strength of the relationship is very apparent in Figure 1, where the probability of computer use is plotted against years of education. ${ }^{9}$ This result is consistent with findings reported in the literature: for example, Arabsheibani et al. (2004) show that years of education have a positive impact in their multivariate analysis of the determinants of computer use.

Figure 1

Standardised Computer Use - Years of Education Relationship

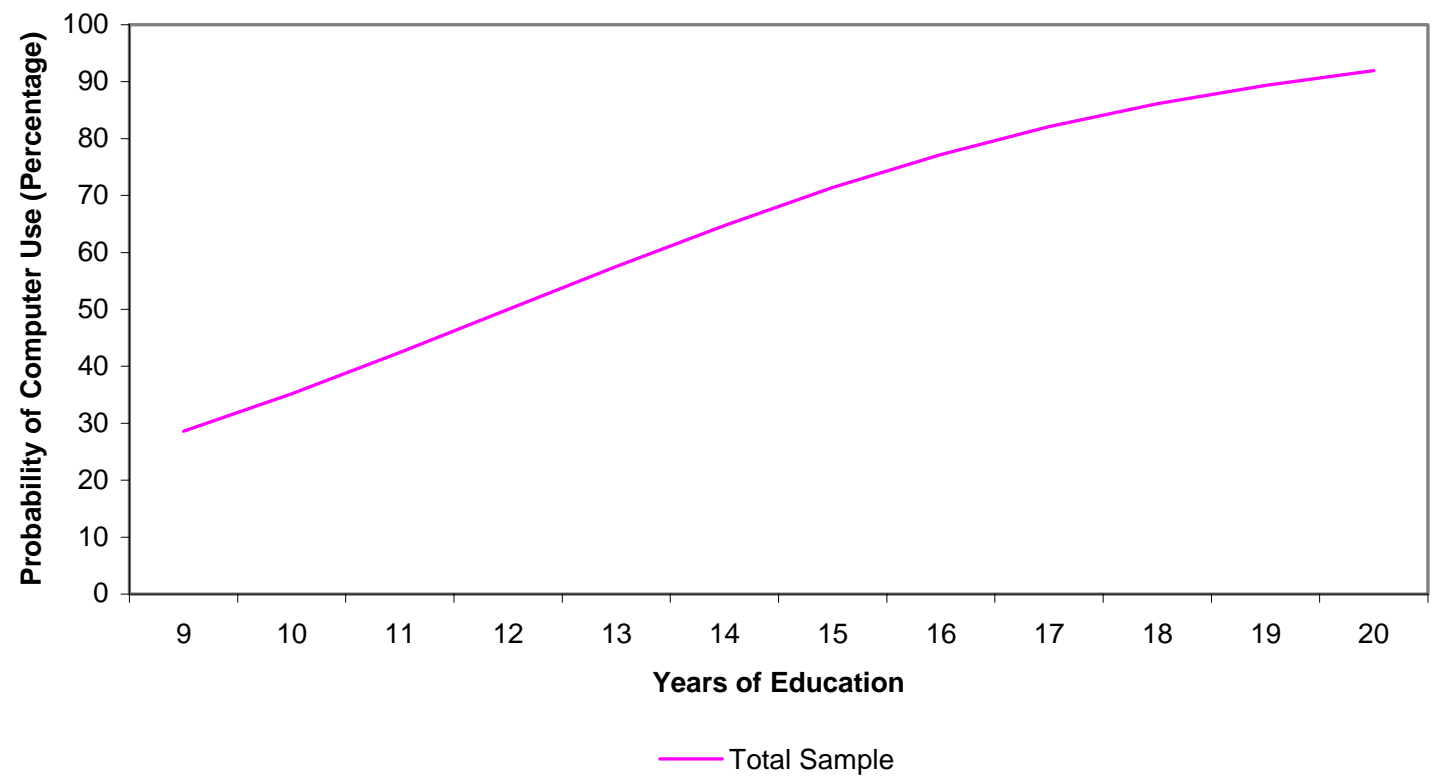

Source: Predictions from Table 3, column (i) using calculated mean values of all the explanatory variables except for Years of Education.

Age was entered into each equation in quadratic form. However, the squared age term was only significant in the equations estimated for the total sample and for that estimated for the Australian born. For those born in Australia the age variables capture both a longitudinal effect (individuals are more likely to have a computer at home with greater wealth, as proxied by age) and a cohort effect (younger cohorts are more computer literate). For those born overseas, as the estimating equation contains controls for years since migration, the age variables record the effects of age at migration.

\footnotetext{
${ }^{9}$ Figure 1 presents only the probability for the total sample since there are no apparent difference between the Australian born and the overseas born in the education-computer use relationship.
} 
The impact of age (and age at migration for the foreign born) on the likelihood of computer use is illustrated in Figure $2 .^{10}$ Two predicted profiles are presented for the overseas born: the first (higher profile) for age at migration, and the second (lower profile) showing the combined effects of years since migration and age. This shows that the Australian born and the overseas born portray quite different behavior in terms of the links between computer usage and age/age at migration. As shown in the figure, for the Australian born the probability of computer use increases slightly with age until around 33 years, and declines more markedly with age beyond that threshold. As the variations in computer use across those aged $20-33$ years are minor, the main age effect is the approximately 8 percentage point difference between the probability of computer use among those aged 33 (born in 1968) and 60 years (born in 1941), that is, between those born after and before the computer revolution. This is likely to reflect cohort differences rather than true age effects.

Figure 2

Standardised Computer Use - Age/Age at Migration Relationship

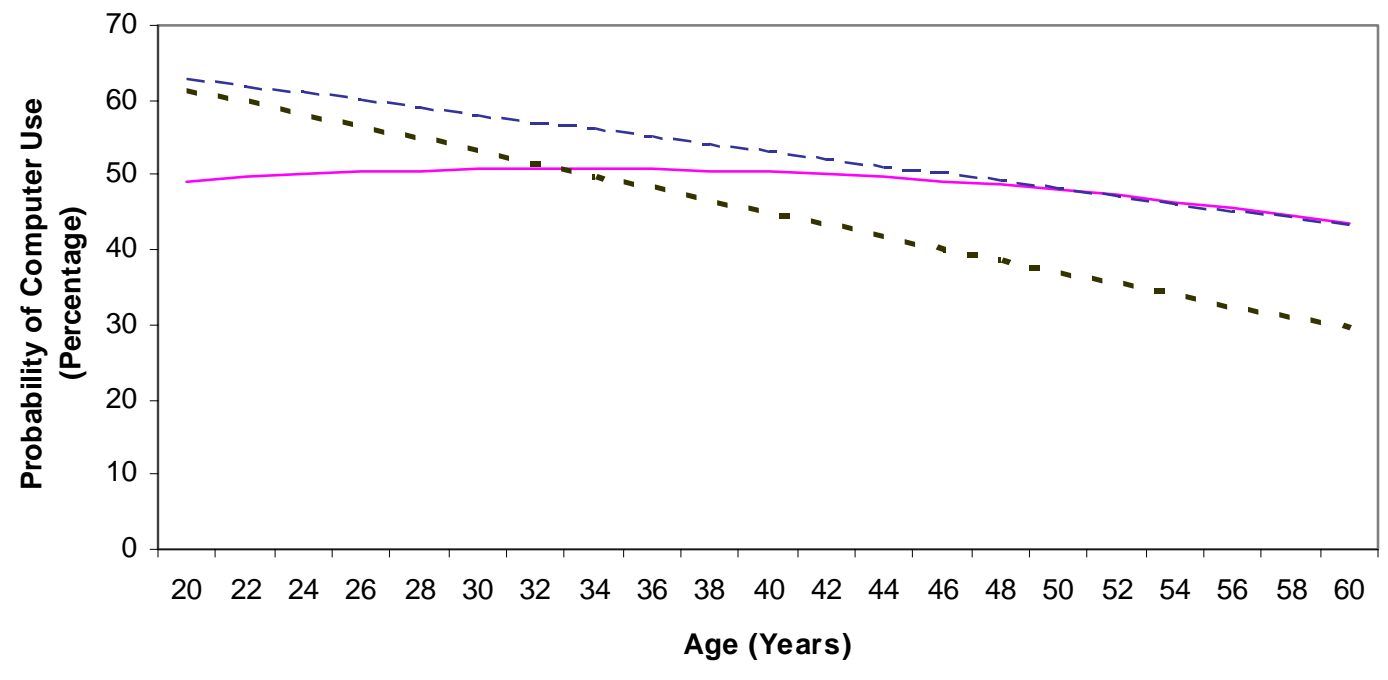

Australian-Born - - - - Overseas-Born (Age only) - - - . Overseas Born (Age+YSM)

Source: Predictions from Table 3, columns (ii) and (iii), using calculated mean values of all the explanatory variables except for Age (and where relevant, years since migration).

${ }^{10}$ The estimates used for the foreign born in Figure 2 are from the model without birthplace fixed effects: curves for the overseas born with birthplace fixed effects are not presented because they are virtually identical to those for the overseas born without birthplace fixed effects. 
This inverted U-shape relationship echoes well the findings by Liu et al. (2004) from the 1999 Taiwan Social Change Survey, where the percentage of computer users tends to increase with age between 20 and 40, and to diminish after that age. Moreover, the results of this paper resemble closely the results from Miller and Mulvey (1997b), based on Australian data from 1993 The Survey of Training and Education (STE), where age had an increasingly positive impact on computer use before the age of 35, and an effect which diminished after that. Each of these comparison studies therefore dates the crucial birth cohort (to have been able to benefit from the computer revolution) as around 1960, which is slightly earlier than the threshold identified from the current study of the 2001 census data, though in the same decade (of the 1960s). It also suggests that the crucial learning environment, at least in the early stages of the computer revolution, was the workplace or universities, as home computers were not common prior to the 1990s.

Among the foreign born, however, the probability of computer usage declines with increasing age at migration. This effect of age on skill acquisition is similar to findings reported from estimation of models of destination language skills among immigrants, where such skills are weaker among immigrants who migrate at an older age. The profile for the overseas born which combines the effects of age and years since migration (that is, it ages immigrants by one year for each additional year they reside in Australia) is, reflecting the negative impact of years since migration (discussed below and illustrated in Figure 3), below the profile that records only age (or age at migration) effects. It indicates that computer use is more likely among immigrants than among the Australian born up to around 33 years, and is less likely for older age groups.

The variable for marital status has to be interpreted jointly with the variable for the education of spouse. The marital status variable effectively serves as a dichotomous variable for the presence of a spouse, and the spouse's education variable is coded as zero if there is no spouse present. Among those married to less-well educated women, the marital status effect is negative. For example, for a male married to a woman with only 8 years of education, the probability of using a computer is 1.7 percentage points less than that of their single counterparts. However, marriage to a better educated woman is associated with an enhanced likelihood of using a computer. For example, evaluated at 15 years of education for the spouse, marital status would have a positive impact on the 
probability of computer use compared to their unmarried counterparts of 8.7 percentage points. ${ }^{11}$ This could reflect the economies (sharing of the fixed cost of a computer) that can be achieved in a multiple-person family, as suggested by the conceptual framework outlined in Section II.

Computer usage is greater (by up to three percentage points per child) among individuals who have a child (or children) under the age of 24 living at home. However, computer usage among individuals who have non-dependent children or other related or unrelated members in the household is less likely, as the probability of computer use is lowered by 3 to 6 percentage points for each extra person with these characteristics in the household. Based on the conceptual framework of Section II, this suggests that these individuals do not contribute to the cost of purchasing this family public good, and indeed may represent a drain on the family budget. Moreover, unlike the situation that prevails with dependent children, the parents in the primary family may not exhibit paternalism towards these other family members, or the way in which this paternalism is expressed varies by family status. ${ }^{12}$

The simplest presentation of the differences between the Australian born and overseas born in the likelihood of using a computer is best seen in Table 3, column (i). In this set of results the coefficient on the foreign-born dichotomous variable is positive, sizeable and highly significant. As duration of residence is held constant in this model, the coefficient on the foreign-born variable when duration equals zero shows that immigrants are 15 percentage points more likely to use computers just after arrival than are the native born. Years since migration, however, are found to have a negative impact on the chances of using a computer. Figure 3 illustrates that the propensity towards computer use among the overseas born decreases toward the native born level with duration until it reaches a "cross-over" point at 28 years of residence in Australia. This pattern most likely reflects cohort effects, with newer cohorts of immigrants being more

${ }^{11}$ Arabsheibani et al. (2004) report that a married person is more likely to use a computer, though the impact was not statistically significant. This may have arisen because no account was taken of the spouse's education level.

${ }^{12}$ Thus, adults may acquire a computer if there are their own teenage children living at home, but not if aged parents live with them. Other family public goods may be in greater demand in the presence of aged relatives. 
computer intensive than longer-term settlers. Further analysis of this issue is presented below when the incidence of computer use is examined separately for the main birthplace groups.

Figure 2

Standardised Computer Use - Years Since Migration Relationship

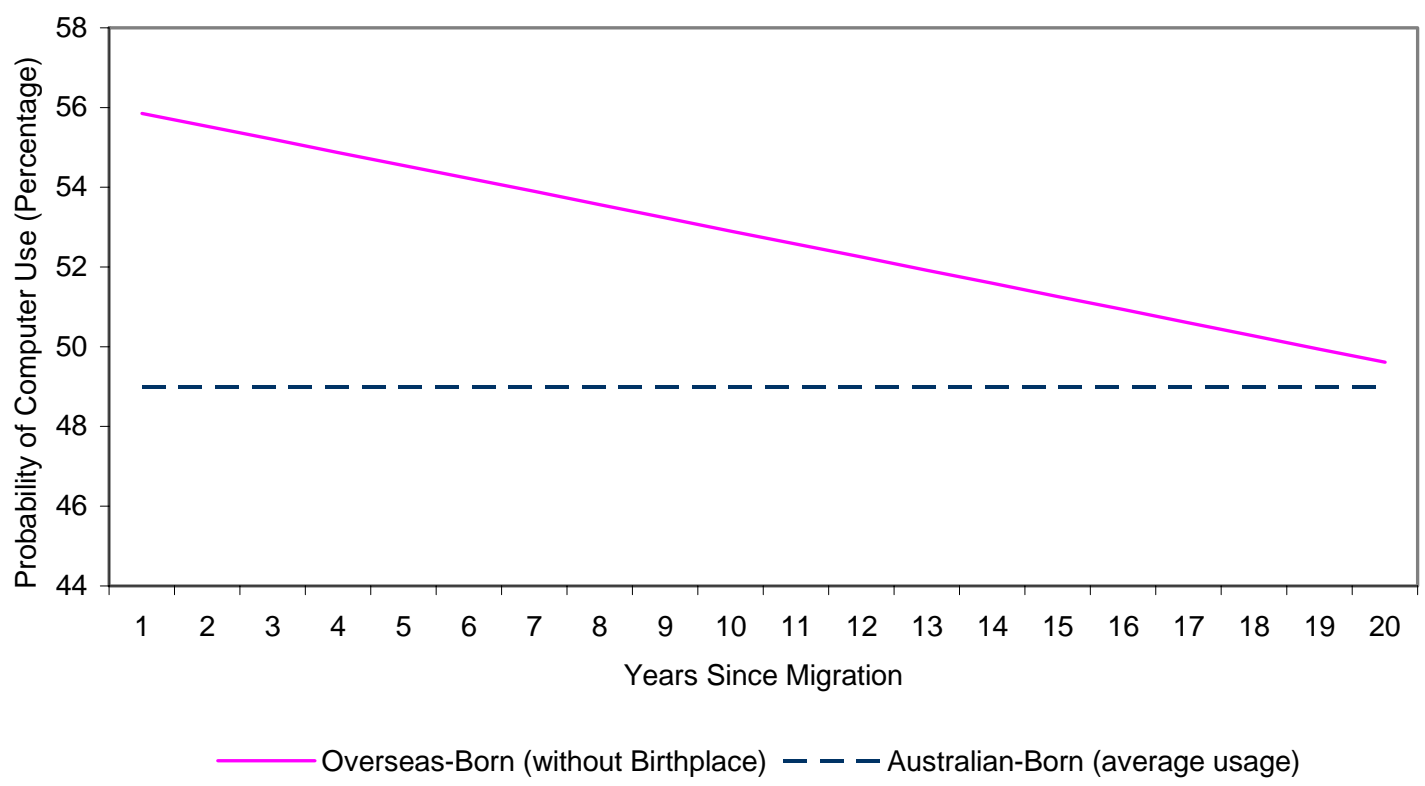

Source: Predictions from Table 3, columns (ii) and (iii), using calculated mean values of all the explanatory variables except for Years Since Migration.

Those who speak languages other than English at home are less likely to use computers than those who speak only English at home, among both the foreign born and those born in Australia. Computer usage declines with a decline in English language proficiency, other variables the same, with the English only speakers reporting greater use than even those who say they speak English "very well". The pattern of effects reveals another complementarity between skills: that is, just as education and computer use have been shown to be complements, so too are English language skills and computer use. $^{13}$

${ }^{13}$ Miller and Mulvey (1997b) also find that those who had more limited English skills are less likely to use computers in the Australian labor market. 
Labor market status has been included in the models, recording the impact on computer use of being unemployed or 'not in the labor force' compared to being employed. The variable 'unemployed' is statistically insignificant in the model, perhaps reflecting a lack of association between a temporary situation (unemployed) and a longterm situation (having a computer at home). It is found that those who are not in the labor force are less inclined (by 2 to 3 percentage points) to use computers at home as compared with those who are employed. The effect of not being in the labor force is slightly stronger for the overseas born than for the native born. ${ }^{14,15}$

Wealth effects in these models are captured by the variables 'number of bedrooms' and 'number of vehicles', when other variables, including the number of household members, are held constant. Both variables are found to have a positive impact on the probability of computer use, and its effect is consistent across the Australian born and foreign born samples. The probability of computer use increases by 3 to 5 percentage points and 4 percentage points, respectively, as the number of bedrooms or number of vehicles increases by one.

Variables for parents' birthplace (whether Australia or not) are included in the model for the Australian born only. It is found that computer use is 8 percentage points lower if both parents are foreign born than if both were born in Australia. It is to be noted, however, that if only the father is foreign-born, the individual's probability of computer use is 4 percentage points greater than those with native born parents, and where only the mother is foreign-born the likelihood of computer use is higher by 5 percentage points. This pattern of findings is not unusual. Chiswick's (1977) analysis of earnings differentials among the native born in the United States found exactly the same order, where having both parents foreign born was associated with a negative impact on

${ }^{14}$ Miller and Mulvey (1997b) and DiNardo and Pischke (1997) contend that full-time workers are more likely to use computers than their part-time counterparts. Miller and Mulvey's (1997b) computer usage variable includes anyone who had ever used a computer, while the DiNardo and Pischke (1997) measure was for on-the-job computer usage.

${ }^{15}$ Males aged 20 to 64 who are not in the labor force are likely to be full-time students (12 percent), disabled, or early retirees (40 percent of those not in the labor force are aged 55-64). 
earnings while having only one parent foreign born was associated with a positive impact on earnings, compared to those with two native born parents.

There is a notable pattern found among the estimates for the 11 birthplace dichotomous variables included in the model for the overseas-born (Table 3, column (iv)). The benchmark birthplace group for this analysis is immigrants from New Zealand. All of the dichotomous variables are statistically significant, with the majority being positive, indicating a greater likelihood of computer use than among immigrants from New Zealand. ${ }^{16}$ Three variables are, however, found to have negative coefficients, indicating that the standardized likelihood of computer use among immigrants from 'South Eastern Europe', 'Middle East and North Africa' and 'Pacific Islands' is less than that for the New Zealanders.

Appendix E contains the logit models of computer use estimated separately by region of birth. A number of the birthplace groups have small samples (between 123 and 225 observations), and the model is not well determined in these cases, in that few of the regressors are statistically significant. Several patterns emerge from the within region of birth analyses.

There is a consistent, and quite strong, positive relationship between educational attainment and the incidence of computer use for each birthplace group. With the exception of those who were born in English-speaking developed countries, there is a negative association between age at migration and the incidence of computer use across most age at migration groups. A higher educational attainment of the spouse among the married is associated with a greater incidence of computer use for all birthplace groups, except Africa. ${ }^{17}$ The positive impact of the presence in the family of dependent children and the negative impact of the presence of non-dependent children or of other related or unrelated individuals observed in the full-sample analysis tend to carry over to the analysis by birthplace. And the complementarity between English language skills and

${ }^{16}$ Given the similarities between Australian and New Zealand, the low cost of migration, and the free mobility between the two countries, New Zealanders in Australia are more like internal migrants than international migrants.

${ }^{17}$ A significant negative effect of spouse's education on computer usage is found only for the small sample of immigrants from Africa (162 observations). The reasons for this atypical finding are unclear. 
computer use in Table 3 tends to carry over to the study of each of the major birthplace regions.

Finally, the computer use - duration of residence relationship is significant for only three birthplace groups - the sizeable groups of immigrants from Europe and South East Asia (where the sign is negative), and for the smaller group from the Pacific Islands (where the sign is positive). The effect for the latter group is at the margin of significance. The negative sign of the period of residence effects for Europe and South East Asia may reflect the composition of the arrival cohorts, with a number of the longer duration of residence groups being refugees who might have different computer literacy than other arrival groups.

\section{The Earnings Consequences of Using Computers}

To estimate the effect of computer usage on earnings, this paper uses a standard human capital earnings function that is augmented with a variable for computer usage, as initially suggested by Krueger (1993). The function takes the following form:

$$
\ln Y_{i}=X_{i} \beta+C_{i} \alpha+\varepsilon_{i}
$$

where income $(Y)$ is a measure of weekly income, $X_{i}$ is a vector of the individual and job-related characteristics that affect the earnings of individual $i, C_{i}$ is a dummy variable for computer usage, $\varepsilon_{i}$ is the error term, and $\beta$ and $\alpha$ are parameters to be estimated, with $\alpha$ being the earnings effect (positive or negative) associated with computer use. The variables considered in $X$ consist of educational attainment, labor market experience and its square, marital status, birthplace, duration of residence for immigrants and English language proficiency. The analyses are restricted to males aged 20 to 64 who were employed in the week before Census night and who reported positive weekly income.

Table 4 presents estimates of earnings equations for the total sample (column (i)), for the Australian born (column (ii) $)^{18}$, for the overseas born without birthplace fixed effects (column (iii)), for the overseas born with birthplace fixed effects (column (iv)), and for the overseas born with birthplace fixed effects and interaction terms between

\footnotetext{
${ }^{18}$ Variables for the birthplace of parents were also considered, but these were statistically insignificant.
} 
proficiency in English and computer usage (column (v)). These models are statistically significant, as indicated by the significant values of the $\mathrm{F}$-tests, and most of the explanatory variables in each model are statistically significant, as shown by the $t-$ ratios.

\section{Table 4}

OLS Estimates of Earnings Equations, By Nativity, Adult Males, 2001 ${ }^{(a)}$

\begin{tabular}{|c|c|c|c|c|c|}
\hline Variables & $\begin{array}{c}\text { Total } \\
\text { Sample }\end{array}$ & $\begin{array}{c}\text { Australian } \\
\text { Born }\end{array}$ & $\begin{array}{l}\text { Overseas } \\
\text { Born } \\
\text { (without } \\
\text { Birthplace } \\
\text { Fixed } \\
\text { Effects) }\end{array}$ & $\begin{array}{c}\text { Overseas } \\
\text { Born (with } \\
\text { Birthplace } \\
\text { Fixed } \\
\text { Effects) }\end{array}$ & $\begin{array}{c}\text { Overseas } \\
\text { Born (with } \\
\text { Birthplace } \\
\text { Fixed } \\
\text { Effects and } \\
\text { Computer } \\
\text { Interaction } \\
\text { Terms) } \\
\text { (v) }\end{array}$ \\
\hline Constant & $\begin{array}{c}4.942 \\
(220.29)\end{array}$ & $\begin{array}{c}4.812 \\
(186.64)\end{array}$ & $\begin{array}{c}5.226 \\
(5.226)\end{array}$ & $\begin{array}{l}5.190 \\
(97.00)\end{array}$ & $\begin{array}{c}5.447 \\
(84.63)\end{array}$ \\
\hline Education & $\begin{array}{c}0.087 \\
(56.27)\end{array}$ & $\begin{array}{c}0.095 \\
(52.49)\end{array}$ & $\begin{array}{c}0.068 \\
(23.25)\end{array}$ & $\begin{array}{c}0.071 \\
(23.74)\end{array}$ & $\begin{array}{c}0.047 \\
(10.48)\end{array}$ \\
\hline Education*Computer & (c) & (c) & (c) & (c) & $\begin{array}{l}0.039 \\
(7.00)\end{array}$ \\
\hline Experience & $\begin{array}{c}0.041 \\
(33.42)\end{array}$ & $\begin{array}{c}0.044 \\
(32.00)\end{array}$ & $\begin{array}{c}0.031 \\
(10.98)\end{array}$ & $\begin{array}{c}0.031 \\
(11.01)\end{array}$ & $\begin{array}{c}0.033 \\
(11.69)\end{array}$ \\
\hline $\begin{array}{l}\text { Experience } \\
\text { squared/100 }\end{array}$ & $\begin{array}{l}-0.071 \\
(28.37)\end{array}$ & $\begin{array}{l}-0.075 \\
(26.46)\end{array}$ & $\begin{array}{l}-0.055 \\
(10.40)\end{array}$ & $\begin{array}{l}-0.056 \\
(10.57)\end{array}$ & $\begin{array}{l}-0.060 \\
(13.50)\end{array}$ \\
\hline Used Computer & $\begin{array}{c}0.087 \\
(12.09)\end{array}$ & $\begin{array}{l}0.074 \\
(9.08)\end{array}$ & $\begin{array}{l}0.118 \\
(7.83)\end{array}$ & $\begin{array}{l}0.122 \\
(8.05)\end{array}$ & $\begin{array}{l}-0.324 \\
(4.66)\end{array}$ \\
\hline $\begin{array}{l}\text { Computer* Speak } \\
\text { English (Very Well) }\end{array}$ & (c) & (c) & (c) & (c) & $\begin{array}{l}-0.076 \\
(2.19)\end{array}$ \\
\hline $\begin{array}{l}\text { Computer* Speak } \\
\text { English (Well) }\end{array}$ & (c) & (c) & (c) & (c) & $\begin{array}{l}-0.139 \\
(3.24)\end{array}$ \\
\hline $\begin{array}{l}\text { Computer* Speak } \\
\text { English (Not Well) }\end{array}$ & (c) & (c) & (c) & (c) & $\begin{array}{l}-0.175 \\
(2.33)\end{array}$ \\
\hline Married & $\begin{array}{c}0.164 \\
(20.81)\end{array}$ & $\begin{array}{c}0.164 \\
(18.26)\end{array}$ & $\begin{array}{c}0.167 \\
(10.00)\end{array}$ & $\begin{array}{l}0.166 \\
(9.96)\end{array}$ & $\begin{array}{l}0.158 \\
(9.53)\end{array}$ \\
\hline Foreign Born & $\begin{array}{l}-0.082 \\
(3.85)\end{array}$ & (c) & (c) & (c) & (c) \\
\hline $\begin{array}{l}\text { Years Since } \\
\text { Migration }\end{array}$ & $\begin{array}{l}0.004 \\
(3.70)\end{array}$ & (c) & $\begin{array}{l}0.004 \\
(3.59)\end{array}$ & $\begin{array}{l}0.004 \\
(3.18)\end{array}$ & $\begin{array}{l}0.004 \\
(2.97)\end{array}$ \\
\hline \multicolumn{6}{|c|}{ English Skills (Speaks only English at Home) } \\
\hline $\begin{array}{l}\text { Speak English Very } \\
\text { Well }\end{array}$ & $\begin{array}{l}-0.079 \\
(6.37)\end{array}$ & $\begin{array}{l}-0.042 \\
(2.43)\end{array}$ & $\begin{array}{l}-0.105 \\
(5.97)\end{array}$ & $\begin{array}{l}-0.050 \\
(2.21)\end{array}$ & $\begin{array}{l}-0.013 \\
(0.43)\end{array}$ \\
\hline Speak English Well & $\begin{array}{l}-0.227 \\
(11.17)\end{array}$ & $\begin{array}{l}-0.249 \\
(3.31)\end{array}$ & $\begin{array}{l}-0.242 \\
(11.34)\end{array}$ & $\begin{array}{l}-0.159 \\
(5.86)\end{array}$ & $\begin{array}{l}-0.118 \\
(3.83)\end{array}$ \\
\hline
\end{tabular}




\begin{tabular}{|c|c|c|c|c|c|}
\hline $\begin{array}{l}\text { Speak English Not } \\
\text { Well }\end{array}$ & $\begin{array}{l}-0.218 \\
(7.47)\end{array}$ & $\begin{array}{l}-0.266 \\
(1.84)\end{array}$ & $\begin{array}{l}-0.249 \\
(8.48)\end{array}$ & $\begin{array}{l}-0.136 \\
(3.81)\end{array}$ & $\begin{array}{l}-0.140 \\
(3.81)\end{array}$ \\
\hline $\begin{array}{l}\text { Speak English Not at } \\
\text { All }\end{array}$ & $\begin{array}{l}-0.459 \\
(6.71)\end{array}$ & $\begin{array}{l}-0.275 \\
(38.24)\end{array}$ & $\begin{array}{l}-0.519 \\
(7.59)\end{array}$ & $\begin{array}{l}-0.320 \\
(4.25)\end{array}$ & $\begin{array}{l}-0.386 \\
(5.22)\end{array}$ \\
\hline \multicolumn{6}{|c|}{ Birthplace (New Zealand) ${ }^{(\mathrm{b})}$} \\
\hline $\begin{array}{l}\text { Other English } \\
\text { Speaking Developed } \\
\text { Countries }\end{array}$ & (c) & (c) & (c) & $\begin{array}{l}0.018 \\
(0.74)\end{array}$ & $\begin{array}{l}0.017 \\
(0.70)\end{array}$ \\
\hline $\begin{array}{l}\text { Europe (except } \\
\text { South Eastern } \\
\text { Europe and United } \\
\text { Kingdom and } \\
\text { Ireland) }\end{array}$ & (c) & (c) & (c) & $\begin{array}{l}0.004 \\
(0.12)\end{array}$ & $\begin{array}{l}-0.001 \\
(0.04)\end{array}$ \\
\hline $\begin{array}{l}\text { South Eastern } \\
\text { Europe }\end{array}$ & (c) & (c) & (c) & $\begin{array}{l}0.006 \\
(0.16)\end{array}$ & $\begin{array}{l}-0.010 \\
(0.27)\end{array}$ \\
\hline Africa & (c) & (c) & (c) & $\begin{array}{r}0.039 \\
(0.71)\end{array}$ & $\begin{array}{l}0.042 \\
(0.75)\end{array}$ \\
\hline $\begin{array}{l}\text { Middle East and } \\
\text { North Africa }\end{array}$ & (c) & (c) & (c) & $\begin{array}{l}-0.132 \\
(3.14)\end{array}$ & $\begin{array}{l}-0.133 \\
(3.17)\end{array}$ \\
\hline South East Asia & (c) & (c) & (c) & $\begin{array}{l}-0.051 \\
(1.47)\end{array}$ & $\begin{array}{l}-0.053 \\
(1.54)\end{array}$ \\
\hline China & (c) & (c) & (c) & $\begin{array}{l}-0.274 \\
(6.01)\end{array}$ & $\begin{array}{r}-0.250 \\
(5.50)\end{array}$ \\
\hline $\begin{array}{l}\text { Southern and Central } \\
\text { Asia }\end{array}$ & (c) & (c) & (c) & $\begin{array}{l}-0.075 \\
(2.03)\end{array}$ & $\begin{array}{l}-0.074 \\
(2.00)\end{array}$ \\
\hline Pacific Islands & (c) & (c) & (c) & $\begin{array}{l}-0.042 \\
(1.02)\end{array}$ & $\begin{array}{l}-0.051 \\
(1.22)\end{array}$ \\
\hline Japan and Korea & (c) & (c) & (c) & $\begin{array}{l}-0.197 \\
(2.68)\end{array}$ & $\begin{array}{l}-0.162 \\
(2.20)\end{array}$ \\
\hline Latin America & (c) & (c) & (c) & $\begin{array}{l}-0.054 \\
(1.08)\end{array}$ & $\begin{array}{r}-0.045 \\
(0.92)\end{array}$ \\
\hline Adjusted $\mathrm{R}^{2}$ & 0.205 & 0.214 & 0.187 & 0.197 & 0.204 \\
\hline $\mathrm{F}$ - test $^{(\mathrm{d})}$ & 701.02 & 676.27 & 176.26 & 88.47 & 77.68 \\
\hline Sample size & 29,888 & 22,274 & 7,614 & 7,614 & 7,614 \\
\hline
\end{tabular}

Source: 2001 Census Household Sample File (HSF).

Notes: (a) Heteroscedasticity 't' statistics in parentheses.

(b) The birthplaces have been grouped regionally; see Appendix B for detailed listing of countries comprising each regional group.

(c) Variable not relevant.

(d) Test that all slopes coefficients are simultaneously equal to zero.

Years of education have a strong positive impact on earnings, with each extra year of educational attainment being associated with 8.7 percent higher earnings for the total 
male workforce (Table 4, column (i)). ${ }^{19}$ The increments in earnings associated with years of education are 3 percentage points higher for the Australian born (10 percent) than for the overseas born (7 percent). ${ }^{20}$

Labor market experience is measured in this analysis using the Mincer proxy, (age - years of schooling -5). This measure of experience is entered into the estimating equation in the usual quadratic form. Evaluated at 10 years of experience, the partial effect is found at 2.9 percent for the Australian born and 2.0 percent for the overseas born. ${ }^{21}$ In addition, it is noted that the experience-wage profile for the Australian born peaks when their experience reaches 29 years, and it peaks at a similar level of experience (28 years) for the overseas born. ${ }^{22}$

Across all models, the variable for marital status is associated with a substantial positive impact on earnings. Those who are married earn around 18 percent more than

19 This return is comparable to the 8 percent reported by Miller and Neo (2003) on the basis of study of 1991 Census data.

20 This pattern has previously been reported by Chiswick and Miller (1985), where, based on analysis of data for 1981, the return to schooling for the Australian born was 8.2 percent and that for the overseas born was 6.1 percent. Similar differentials between the overseas born and native born have been found for other labor markets, for example, in Chiswick's (1978) study of the US and Baker and Benjamin's (1994) study for Canada. For a recent analysis of the reasons for this difference, see Chiswick and Miller (2005a).

${ }^{21}$ When evaluated at this level of experience, Chiswick and Miller (1985) report a much lower return to experience for both the Australian born and the overseas born (1.6 and 1.0 percent respectively) for the 1981 Census. This difference appears to be due to the different age coverage of the two studies: Chiswick and Miller (1985) focus on 25 - 64 year olds, compared to the slightly wider age group (20-64 year olds) examined in this study. When the equations in Table 6 were re-estimated for 25 - 64 year olds, the returns to experience were found to be 1.7 percent for the Australian born and 1.0 percent for the overseas born, when evaluated at 10 years of experience, remarkably close to the 1981 Census results.

${ }^{22}$ Miller and Neo (2003) report a similar result, with, for example, the earnings profile for the Australian sample in their study peaking at 27 years of experience. 
those who are not married. This result is consistent with Krueger's (1993) finding for the US, but it is much greater than the findings reported by other Australian studies. ${ }^{23}$

It is found that at arrival (years since migration equal to zero) the foreign born are at a wage disadvantage of around 8 percent as compared to the native born. This is consistent with the Australian literature, with the result falling in the middle of the range of findings reported previously. ${ }^{24}$

The earnings of the foreign born increase with duration of residence by around one-half of a percentage point per additional year of residence. Consequently, the foreign born's earnings performance catches up with that of the native born after around 20 years of residence in Australia. This is a much faster rate of catch up than has previously been reported in Australia. Chiswick and Miller (1985), for example, report that the gap will never close (predicted to close at about 50 years of residence in Australia) on the basis of study of 1981 Census data, whereas Miller and Neo (2003) report that the income gap between the Australian born and the overseas born will converge after 31 years on the basis of analysis of 1991 Census data. The 2001 Census data are, however, consistent with studies for the United States (Chiswick (1978)).

Four dichotomous variables are used in the models to capture the effects of English language proficiency on earnings. These variables categorize the English skills of individuals who speak a language other than or in addition to English at home into four different levels: very well, well, not well and not at all. Individuals who speak a language other than English at home earn less compared to those who speak only English at home, among both the overseas born and the Australian born. The results show that the wage penalties associated with being bilingual or a non-English speaking monolingual are inversely related to English language proficiency. In the full sample (Table 4, column (i)), those who speak English very well earn 7.9 percent less than those who are

\footnotetext{
${ }^{23}$ Miller and Mulvey (1997a) and Voon and Miller (2005) reported a wage gain of only 9 percent, while Chiswick and Miller (1985) find that married men earn 13 percent more than the unmarried.

${ }^{24}$ Miller and Mulvey (1997a) report a wage gap of around 3 to 4 percent and Chiswick and Miller's (1985) results indicate a 5 to 7 percent of wage disadvantage, whereas Miller and Neo (2003) report a wage gap of 12 percent.
} 
monolingual English speakers, while those who speak English not at all have a wage penalty of 58 percent compared to monolingual English speakers. ${ }^{25}$ These wage effects associated with English language skills are broadly the same for the Australian born and the overseas born, and the results emphasize the value of English language proficiency in the Australian labor market. ${ }^{26}$

The variable for computer usage indicates that this activity has a positive effect on earnings across all models. The return to computer use is higher for the overseas born (about 13 percent) than for the Australian born (around 7 percent) (Table 4, column (ii) and (iii)). ${ }^{27}$ These percentage effects amount to annual increases, in Australian dollars, of about AUD\$6,000 and AUD\$3,300, respectively. ${ }^{28,29}$ In contrast, in 2001 a computer and printer would have cost AUD\$2,700, or about AUD\$900 a year over a three-year lifespan, and a one year internet connection would have cost around AUD\$600, for a total annual cost of about AUD $\$ 1,500$. Therefore, ignoring the cost of learning how to use a computer, which for those who have not had childhood exposure to computers may not be trivial, and ignoring the value of the time put into home computer use, the use of

25 These findings are in accordance with the results of Miller and Mulvey (1997a), who reported wage penalties of 7 and 18 percent for those who have some difficulties and extreme difficulties with the English language, respectively. Similarly, Chiswick and Miller (1985) report a wage penalty of 11 percent for those who speak a language other than English at home, with the earnings of individuals who have poor mastery over the English language being a further 4 percent lower.

${ }^{26}$ Those who speak English very well earn 4 percent less than monolingual English speakers among the Australian born, and 11 percent less among the overseas born. This earnings differential among the native born has also been found for the US (Fry and Lowell (2003), Chiswick and Miller (1998)).

${ }^{27}$ In this paper, the percentage impact on wages is calculated using 100[exp(estimate)-1] (see Halvorsen and Palmquist (1980)) for those estimates that are greater than 0.1, whereas all the remaining estimates will be interpreted as percentage effects.

28 In 2001 the Australian dollar was equivalent to approximately 0.5 US dollars. It is currently (2005) around 0.75 US dollars.

29 These wage gains from computer use are found to be close to most of the results reported in the literature (for example, Dolton and Makepeace (2004) found a wage premium of $12-16$ percent, and the premium was $10-15$ percent in Krueger (1993), and 12 percent in Miller and Mulvey (1997a)). 
computers at home appears to be a highly profitable investment with respect to labor market earnings for both the native born and the overseas born. ${ }^{30}$

An IV estimator was also applied, as it is possible variations in computer use across the sample are in response to the monetary incentives in the labor market. However, the pseudo $\mathrm{R}^{2} \mathrm{~s}$ in the estimates of the determinants of computer use presented in Section IV are quite low, and, consequently, it can be expected that the instruments for computer use in the earnings equation will be weak. Indeed, the results from the IV estimator varied greatly. For example, for the full sample the IV coefficient on the computer use variables was 0.224 (' $\mathrm{t}$ ' $=4.67$ ), for the Australian born it was 0.033 (' $\mathrm{t}$ ' $=$ 0.60 ), and for the foreign born 0.529 (' $t$ ' $=5.52$ ). These highly variable results mirror findings from studies that have applied an IV estimator when examining the effects of language skills on earnings (e.g., Chiswick and Miller (1995)). ${ }^{31}$ As the IV estimates are not of a reasonable magnitude, they do not appear to be informative, and are not considered further here.

As an extension to the model for the overseas born, the education and various levels of English skills variables were interacted with the computer usage variable (Table 4, column v). There were no foreign born workers who were monolingual non-English speakers who used computers (a telling point in itself), and hence only three interaction terms for English skills are included in the model.

The interaction term between the level of educational attainment and the variable for computer use among the overseas born is positive (coefficient 0.039) and highly significant. ${ }^{32}$ Together with the coefficient on the education variable, it shows that the partial effect of an extra year of schooling is around 9 percent among those who use computers and only 5 percent among immigrant men who do not use computers.

The interactions of the computer variable with the English language proficiency

\footnotetext{
${ }^{30}$ These computations ignore the consumption benefits from using a computer at home.

${ }^{31}$ Dustmann and van Soest's (2001) findings imply that correlated unobserved heterogeneity in earnings and computer use will result in an upward bias in the IV estimates.
}

${ }^{32}$ A similar interaction term was insignificant when included in the estimating equation for the native born. 
dichotomous variables (with the English only speakers serving as the benchmark) all have negative coefficients that are highly statistically significant. The absolute magnitude of these coefficients increase with a decrease in English language proficiency. The coefficients indicate that those who speak only English have earnings that are 1.3 percent higher than those who speak English very well if they do not use computers, but the earnings advantage of immigrant English only speakers increases to 9 percent (1.3 percent plus 7.6 percent) if they use computers. Comparing the English only speakers to those who speak English "well" the earnings advantage is 12 percent if they do not use computers and about 26 percent if they do. This implies a complementarity in the generation of earnings between English proficiency and computer use among immigrants. English proficiency and computer use each, separately, enhance earnings, but the impact is greater when combined, that is, when the most proficient use a computer. ${ }^{33}$

When the various interaction terms are added to the model, the coefficient on the computer use variable is negative. However, it needs to be evaluated along with the interaction terms between the use of computers and level of education and English language skills to determine the impact of computer use on earnings. Hence the partial effect of computer use on earnings (among those who speak only English) is given as $-0.324+0.0393 * E d u c$ (Table 4, column (v)). For all levels of education greater than eight years this effect will be positive. At the mean level of education this effect is around 15 percent, and for those with university degrees it would be even higher, at around 30 percent. This emphasizes the complementarity in generating earnings between educational and computer skills among the foreign born.

As the interaction term between computer use and level of education was insignificant among the native born, it is conjectured that the use of a computer is a way the foreign born can increase the international transferability of the skills they acquired through the formal education system in the country of origin.

The effect on the earnings equation for the overseas born of birthplace fixed effects is shown by the introduction of the region of birth dichotomous variables

${ }^{33}$ This is comparable to the apparent complementarity of English language proficiency and other human capital (schooling and experience) in Canada (Chiswick and Miller (2003)). 
(compare Table 4, columns iii and iv). When they are added to the model there is little effect on the coefficient of education (an increase from 6.8 percent to 7.1 percent), and essentially no changes in the effects on earnings of labor market experience, duration in Australia, being married or computer use (an increase in the latter from only 11.8 to 12.2 percent). However, because of correlation between the birthplace variables and English language proficiency, the measured negative impact on earnings of limited proficiency is reduced in absolute magnitude.

With New Zealand immigrants as the benchmark, only four birthplace variables are statistically significant. These four birthplaces, namely 'Middle East and North Africa', 'China', 'Southern and Central Asia' and 'Japan and Korea', exhibit negative impacts on earnings. This implies that men who were born in these countries would earn 8 to 32 percent less than immigrants to Australia from New Zealand.

It is interesting to note, even when reported English language speaking skills are held constant, immigrants with mother tongues that are the most linguistically distant from English (Chinese, Japanese, Korean, Arabic) receive the lowest earnings (Chiswick and Miller 2005b). This may arise from their having poorer speaking skills within each proficiency category or from poorer English reading and writing skills within English speaking categories.

\section{Summary and Conclusion}

This paper studies the determinants of computer use at home and the impact of computer skills and destination language proficiency on the earnings of the native born and immigrants in Australia, using data from the 2001 Australian Census Household Sample File (HSF). The sample for the empirical analyses focuses only on males aged 20-64 years old.

A conceptual framework for the study of computer use at home is provided that treats this as a "public good" within the context of family decision making. The model suggests that the demand for computers will depend on the individuals' own characteristics that shape their preferences towards computers, their partner's characteristics, paternalism towards children and other family factors, including the presence in the household of non-dependent children and other relatives.

The logit model of the determinants of computer use at home showed that 
educational attainment and English language skills are complements of computer use, for both the native born and for the foreign born, and among the foreign born, for each of the major birthplace regions. The education level of the spouse and the number of dependent children both have positive effects on the likelihood of using a computer at home, while the number of non-dependent children and the number of other related or unrelated individuals living with the family impact negatively on the likelihood of using a computer at home. Clearly, human capital and family circumstances matter a great deal to the determinants of home computer ownership and use.

Computer use at home among the native born men age 20 to 64 years in 2001 appears to increase slightly with age until a peak at around 33 years (born in 1968), perhaps reflecting a wealth (consumer durable acquisition) effect. Beyond this point computer usage at home declines sharply with age. That is, those born before the computer revolution, and who attended school before its widespread use in schools, are much less likely as adults to use a computer at home, and the earlier their birth the less likely are they to use a computer. Computer skills, like language skills in general, are easiest to learn as a youth. The decline in use with age among those no longer thirtysomething in 2001 is therefore likely to reflect a cohort phenomenon and not a life-cycle effect.

Among the foreign born, recent arrivals are much more likely (by 15 percentage points) to use computers than the native born. Given the data on internet use by region of the world, which show a relatively high level of usage in Australia, the pattern that emerges in this multivariate analysis is presumably due to a high degree of favorable selectivity in migration by the immigrants and/or by the Australian immigration authorities. While duration in Australia was shown to have a negative impact on computer use in the overall analysis, separate analyses for each of the major birthplace groups indicate that this may reflect the change in the birthplace mix of immigrant cohorts, with newer cohorts of immigrants being more computer literate at arrival than were longer-term settlers.

Computer usage has a positive effect on earnings for both the native born and the foreign born, though its effect is much greater for the foreign born (13 percent compared to around 7 percent for the native born). These annual earnings increments are very large 
compared to the out-of-pocket costs of a computer (hardware and software), printer and internet connection. Depending on the cost of learning computer skills and the time involved in computer use at home, they may imply a very high rate of return to investments in computer literacy and computer use at home. Indeed, this would be consistent with the rapid spread of computer literacy and computers in the home, especially among the younger generation who have grown up in the computer-intensive world and have learned these skills at school.

The effects of computer usage on earnings among the foreign born were shown to be positively related to both the level of educational attainment and the workers' proficiency in English. This shows that these skills are complementary in the generation of earnings. Thus, each of the three skills of formal schooling, English language proficiency and computer usage is, separately, associated with higher earnings. But where a worker does not possess one of these skills, the payoffs to possession of the other skills are lower than they otherwise would have been. The fact that there was an absence of a complementarity in generating earnings between level of education and computer use among the native born, and a strong complementarity between these skills for the foreign born, suggests that the use of a computer is a way the foreign born can increase the international transferability of their pre-immigration human capital skills.

The new focus in this study on the use of computers among immigrants reinforces the main findings that have emerged from the immigrant adjustment literature to date. Namely, there appears to be intense favorable selectivity (by the immigrants and/or immigration authorities) in migration, and that the major human capital skills that immigrants possess are complementary. It shows, moreover, that recent immigrants' apparent favorable disposition to the use of computers offers a way through which the international transferability of formal schooling attained in the country of origin can be enhanced. Immigrant settlement policies could focus on this, as well as on the more conventional destination language skills. The complementarities between these skills suggest, however, that it is preferable to give emphasis to both types of post-arrival skill formation. 


\section{APPENDIX A \\ Frequency Distribution of Language Spoken at Home by Nativity, Adult Males,}

2001

\begin{tabular}{|c|c|c|c|}
\hline Language Spoken at Home & $\begin{array}{c}\text { Australian Born } \\
(\%)\end{array}$ & $\begin{array}{c}\text { Overseas Born } \\
(\%)\end{array}$ & $\begin{array}{c}\text { Total Sample } \\
(\%)\end{array}$ \\
\hline Only English & 94.85 & 54.94 & 83.74 \\
\hline German & 0.11 & 1.11 & 0.39 \\
\hline Netherlandic & (a) & 0.45 & 0.16 \\
\hline French & (a) & 0.77 & 0.26 \\
\hline Greek & 1.31 & 3.01 & 1.79 \\
\hline Portuguese & (a) & 0.44 & 0.15 \\
\hline Spanish & 0.09 & 1.94 & 0.61 \\
\hline Italian & 1.51 & 3.57 & 2.09 \\
\hline Maltese & 0.10 & 0.67 & 0.26 \\
\hline Hungarian & (a) & 0.33 & 0.12 \\
\hline Russian & (a) & 0.39 & 0.13 \\
\hline Croatian & 0.18 & 1.01 & 0.41 \\
\hline Macedonian & 0.21 & 1.20 & 0.49 \\
\hline Serbian & (a) & 0.89 & 0.30 \\
\hline Polish & (a) & 0.91 & 0.31 \\
\hline Persian & N/A & 0.72 & 0.20 \\
\hline Arabic (including Lebanese) & 0.39 & 3.74 & 1.32 \\
\hline Turkish & (a) & 0.95 & 0.30 \\
\hline Tamil & (a) & 0.64 & 0.18 \\
\hline Hindi & (a) & 1.13 & 0.32 \\
\hline Sinhalese & (a) & 0.56 & 0.16 \\
\hline Khmer & N/A & 0.38 & 0.10 \\
\hline Vietnamese & (a) & 3.42 & 0.98 \\
\hline Indonesian & (a) & 0.90 & 0.28 \\
\hline Tagalog (Filipino) & (a) & 1.25 & 0.36 \\
\hline Cantonese & 0.09 & 4.27 & 1.25 \\
\hline Mandarin & (a) & 2.97 & 0.85 \\
\hline Japanese & (a) & 0.44 & 0.16 \\
\hline Korean & (a) & 0.88 & 0.25 \\
\hline Samoan & N/A & 0.34 & 0.09 \\
\hline Other N. and S. European Languages & (a) & 0.37 & 0.13 \\
\hline Other Eastern European Languages & 0.15 & 1.60 & 0.56 \\
\hline $\begin{array}{l}\text { Other Southwest Asian and North African } \\
\text { Languages }\end{array}$ & (a) & 0.60 & 0.19 \\
\hline Other Southern Asian Languages & (a) & 1.64 & 0.47 \\
\hline Other Southeast Asian Languages & (a) & 1.00 & 0.31 \\
\hline Other Eastern Asian Languages & (a) & 0.56 & 0.16 \\
\hline Other Australian Indigenous Languages & 0.27 & (a) & 0.20 \\
\hline Total & 100.00 & 100.00 & 100.00 \\
\hline
\end{tabular}

Source: 2001 Census Household Sample File (HSF). 
Notes: $\quad$ (a) $=$ Cell with sample size under 30 .

N/A = No observation was found for the sub-group. 


\begin{tabular}{ll}
\multicolumn{1}{c}{ Countries Comprising Each Regional Group Used in Analysis } \\
\hline Regions & Countries Comprising \\
\hline New Zealand & New Zealand \\
$\begin{array}{l}\text { Other English Speaking } \\
\text { Developed Countries }\end{array}$ & United Kingdom, Ireland, United States of America, South \\
Europe (except South Eastern & Africa, Other North America \\
Europe, United Kingdom and & Germany, Netherlands, Italy, Other Western Europe, Other \\
Ireland) & Southern Europe, Northern Europe, Poland, Other Eastern \\
South Eastern Europe & Europe \\
Africa & Croatia, Greece, Yugoslavia, Other South Eastern Europe \\
Middle East and North Africa & Central and West Africa, Other Africa \\
South East Asia & Lebanon, North Africa, Other Middle East \\
& Vietnam, Malaysia, Philippines, Other Mainland South- \\
China & East Asia, Other Maritime South-East Asia \\
Southern and Central Asia & China, Hong Kong, Other Chinese Asia \\
Japan and Korea & India, Sri Lanka, Other Southern Asia, Central Asia \\
Pacific Islands & Japan, Korea \\
Latin America & Melanesia, Micronesia, Polynesia \\
\hline Source: Authors' definitions based on & South America, Central America, Caribbean \\
\hline
\end{tabular}




\begin{tabular}{llc}
\multicolumn{3}{c}{$\begin{array}{c}\text { Appendix C } \\
\text { Incidence of Internet Use by Region of the World }\end{array}$} \\
\hline \multicolumn{1}{c}{ Regions } & \multicolumn{1}{c}{$\begin{array}{c}\text { Modified Countries Comprising } \\
\text { each Regional Group }\end{array}$} & Internet users (\%) \\
\hline Australia & Australia & 53.87 \\
New Zealand & New Zealand & 52.13 \\
Other English Speaking & United Kingdom, Ireland, United & 51.66 \\
Developed Countries & States of America, South Africa \\
Europe (except South Eastern & Germany, Italy, Netherlands, & \\
Europe, United Kingdom and & Poland & 34.58 \\
Ireland) & & \\
South Eastern Europe & Croatia, Greece & \\
Africa & Central Africa Republic & 12.46 \\
Middle East and North Africa & Lebanon & 0.0005 \\
South East Asia & Vietnam, Malaysia, Philippines & 8.05 \\
China & China, Hong Kong & 5.60 \\
Southern and Central Asia & India, Sri Lanka & 3.87 \\
Japan and Korea & Japan, South Korea & 0.67 \\
Pacific Islands & Micronesia & 46.49 \\
Latin America & Mexico, Panama, Argentina, & 1.85 \\
& Brazil, Paraguay, Uruguay & 8.44 \\
\hline Source: CIA The World Fachoo & \\
\hline
\end{tabular}

Source: CIA The World Factbook 2003. 


\section{Appendix D \\ Definitions of Variables}

This appendix contains brief description of all variables used in the multivariate analyses. It also presents the questions on computer use and internet use included on the 2001 Census form.

\section{Dependent Variables}

Log of Weekly Earnings Natural logarithm of weekly earnings (where earnings are defined as gross earnings from all sources). Midpoints of intervals were used to construct a continuous measure. The open-ended upper category was assigned a value of 1.5 times the lower threshold level.

Computer Use

Binary indicator, set equal to one where the respondent had used a computer at home in the previous week.

\section{Explanatory Variables}

Years of Education

This is a continuous variable that records the equivalent years of full-time education completed by the individual. Individuals holding a Postgraduate degree are assigned 19 years of education, Graduate Diploma and Graduate Certificate holders are assumed to have 17 years, Bachelor degree holders have the equivalent of 15.5 years of education, advanced Diploma and Diploma holders are coded as having 14 years, holders of Certificate are assigned 13 years, those who have completed either Year 9 or any years through to Year 12 are coded as 9, 10, 11 and 12 year of education, respectively, and those who did not go to school or attained Year 8 or below are assumed to have 7 years of education.

Age

Marital Status

This is a continuous variable for age.

Binary variable set to one if an individual is married, spouse present, and set to zero otherwise.

Family Structure

Three continuous variables record the number of dependent children, number of non-dependent children, and number of other related or unrelated members in an individual's household.

Birthplace of individual

Defined to equal one for individuals who were born overseas (Foreign Born) and zero for Australian born. Birthplaces for the Foreign Born are: New Zealand (benchmark region), Other English Speaking Developed Countries, Europe, South Eastern Europe, Africa, Middle East and North Africa, South East Asia, China, Southern and Central Asia, Pacific Islands, Japan and Korea, and Latin America. Overseas visitors are deleted 
Duration of Residence in Australia

Experience

English Language

Proficiency

Labor Market Status

Wealth Status

Parents’ Birthplace from the sample.

The number of years an individual born overseas has lived in Australia, constructed by taking the mid-point of the period of residence interval.

Age - Years of Education - 5 .

Four dichotomous variables for individuals who speak a language other than English at home: 'Speak English Very Well', 'Speak English Well', 'Speak English Not Well', and 'Speak English Not At All'. The reference group is those who speak English at home.

Only two dichotomous variables 'unemployed' and 'Not in Labor Force' are set to equal one for individuals in these categories. The reference group is being employed.

Two continuous variables 'Number of Bedrooms' and 'Number of Vehicles'. These are coded in ordinal number from ' 0 ' to ' 5 ' for 0 bedrooms to 5 or more bedrooms and from ' 0 ' to ' 4 ' for 0 vehicles to 4 or more vehicles.

Three dummy variables for the native born: 'Both Parents Foreign Born', 'Only Father Foreign Born', and 'Only Mother Foreign Born'. The benchmark is having both parents born in Australia.

The questions on computer use at home and internet use on the 2001 Census Household Form are as follows:

- Did the person use a personal computer at home last week?

\begin{tabular}{|l|l|}
\hline & No \\
\hline & Yes \\
\hline
\end{tabular}

- Did the person use the Internet anywhere last week? (Mark all applicable boxes)

\begin{tabular}{|l|l|}
\hline & No \\
\hline & Yes, at home \\
\hline & Yes, at work \\
\hline & Yes, elsewhere \\
\hline
\end{tabular}


Appendix E

Estimates of Logit Models of Computer Use for those Born Overseas, by Region of Birth, $2001{ }^{\text {(a) (b) }}$

\begin{tabular}{|c|c|c|c|c|c|c|c|c|c|c|c|c|}
\hline Variables & $n z^{(\mathrm{d})}$ & ukus & euro & seeuro & africa & miden & seasia & china & sthcent & pac & japko & latam \\
\hline Constant & $\begin{array}{l}-3.914 \\
(6.18)\end{array}$ & $\begin{array}{c}-4.633 \\
(6.85)\end{array}$ & $\begin{array}{c}-1.444 \\
(2.47)\end{array}$ & $\begin{array}{l}-2.446 \\
(2.70)\end{array}$ & $\begin{array}{l}-2.769 \\
(1.53)\end{array}$ & $\begin{array}{l}-3.058 \\
(4.03)\end{array}$ & $\begin{array}{l}-0.253 \\
(0.21)\end{array}$ & $\begin{array}{l}3.663 \\
(1.96)\end{array}$ & $\begin{array}{l}0.769 \\
(0.45)\end{array}$ & $\begin{array}{l}-6.914 \\
(4.49)\end{array}$ & $\begin{array}{c}-2.174 \\
(0.90)\end{array}$ & $\begin{array}{l}-5.327 \\
(3.43)\end{array}$ \\
\hline Education & $\begin{array}{l}0.275 \\
(6.67)\end{array}$ & $\begin{array}{c}0.249 \\
(12.28)\end{array}$ & $\begin{array}{c}0.286 \\
(10.25)\end{array}$ & $\begin{array}{l}0.358 \\
(6.92)\end{array}$ & $\begin{array}{l}0.345 \\
(3.14)\end{array}$ & $\begin{array}{l}0.237 \\
(5.48)\end{array}$ & $\begin{array}{l}0.312 \\
(8.70)\end{array}$ & $\begin{array}{l}0.238 \\
(4.50)\end{array}$ & $\begin{array}{l}0.157 \\
(3.27)\end{array}$ & $\begin{array}{l}0.438 \\
(4.65)\end{array}$ & $\begin{array}{l}0.495 \\
(3.12)\end{array}$ & $\begin{array}{l}0.448 \\
(4.45)\end{array}$ \\
\hline Age & $\begin{array}{l}0.009 \\
(1.23)\end{array}$ & $\begin{array}{l}0.059 \\
(2.05)\end{array}$ & $\begin{array}{l}-0.034 \\
(4.66)\end{array}$ & $\begin{array}{l}-0.044 \\
(3.76)\end{array}$ & $\begin{array}{l}-0.064 \\
(2.35)\end{array}$ & $\begin{array}{l}-0.028 \\
(2.56)\end{array}$ & $\begin{array}{l}-0.110 \\
(2.02)\end{array}$ & $\begin{array}{l}-0.221 \\
(2.65)\end{array}$ & $\begin{array}{l}-0.134 \\
(1.70)\end{array}$ & $\begin{array}{l}0.017 \\
(0.91)\end{array}$ & $\begin{array}{l}-0.118 \\
(3.28)\end{array}$ & $\begin{array}{l}-0.028 \\
(1.65)\end{array}$ \\
\hline $\begin{array}{l}\text { Age } \\
\text { Squared/100 }\end{array}$ & (c) & $\begin{array}{l}-0.078 \\
(2.39)\end{array}$ & (c) & (c) & (c) & (c) & $\begin{array}{l}0.117 \\
(1.76)\end{array}$ & $\begin{array}{l}0.212 \\
(2.17)\end{array}$ & $\begin{array}{l}0.105 \\
(1.14)\end{array}$ & (c) & (c) & (c) \\
\hline Married & $\begin{array}{l}-1.587 \\
(2.89)\end{array}$ & $\begin{array}{l}-0.473 \\
(1.66)\end{array}$ & $\begin{array}{l}-0.541 \\
(1.37)\end{array}$ & $\begin{array}{c}-0.021 \\
(0.03)\end{array}$ & $\begin{array}{l}3.020 \\
(1.89)\end{array}$ & $\begin{array}{l}-1.191 \\
(1.85)\end{array}$ & $\begin{array}{l}-0.550 \\
(1.02)\end{array}$ & $\begin{array}{l}-1.641 \\
(1.91)\end{array}$ & $\begin{array}{l}-0.886 \\
(1.15)\end{array}$ & $\begin{array}{l}-2.923 \\
(2.00)\end{array}$ & $\begin{array}{c}-4.503 \\
(1.41)\end{array}$ & $\begin{array}{l}-0.308 \\
(0.25)\end{array}$ \\
\hline $\begin{array}{l}\text { Education of } \\
\text { Spouse }\end{array}$ & $\begin{array}{l}0.132 \\
(3.05)\end{array}$ & $\begin{array}{l}0.067 \\
(3.02)\end{array}$ & $\begin{array}{l}0.078 \\
(2.52)\end{array}$ & $\begin{array}{c}-0.0005 \\
(0.01)\end{array}$ & $\begin{array}{l}-0.246 \\
(2.05)\end{array}$ & $\begin{array}{l}0.130 \\
(2.66)\end{array}$ & $\begin{array}{l}0.021 \\
(0.52)\end{array}$ & $\begin{array}{l}0.091 \\
(1.47)\end{array}$ & $\begin{array}{l}0.095 \\
(1.74)\end{array}$ & $\begin{array}{l}0.232 \\
(2.07)\end{array}$ & $\begin{array}{l}0.286 \\
(1.21)\end{array}$ & $\begin{array}{l}0.063 \\
(0.64)\end{array}$ \\
\hline $\begin{array}{l}\text { Number of } \\
\text { Dependent } \\
\text { Children }\end{array}$ & $\begin{array}{l}0.191 \\
(2.77)\end{array}$ & $\begin{array}{l}0.119 \\
(2.59)\end{array}$ & $\begin{array}{l}-0.108 \\
(1.59)\end{array}$ & $\begin{array}{l}0.049 \\
(0.45)\end{array}$ & $\begin{array}{l}0.668 \\
(2.49)\end{array}$ & $\begin{array}{l}0.018 \\
(0.23)\end{array}$ & $\begin{array}{l}0.055 \\
(0.71)\end{array}$ & $\begin{array}{l}0.462 \\
(2.98)\end{array}$ & $\begin{array}{l}0.162 \\
(1.35)\end{array}$ & $\begin{array}{l}0.028 \\
(0.17)\end{array}$ & $\begin{array}{l}0.406 \\
(0.96)\end{array}$ & $\begin{array}{l}0.219 \\
(1.24)\end{array}$ \\
\hline $\begin{array}{l}\text { Number of } \\
\text { Non- } \\
\text { Dependent } \\
\text { Children }\end{array}$ & $\begin{array}{l}-0.102 \\
(0.74)\end{array}$ & $\begin{array}{l}-0.205 \\
(2.41)\end{array}$ & $\begin{array}{l}-0.339 \\
(3.07)\end{array}$ & $\begin{array}{l}-0.482 \\
(2.61)\end{array}$ & $\begin{array}{l}-0.204 \\
(0.44)\end{array}$ & $\begin{array}{l}-0.150 \\
(1.06)\end{array}$ & $\begin{array}{l}-0.098 \\
(0.81)\end{array}$ & $\begin{array}{l}0.427 \\
(1.84)\end{array}$ & $\begin{array}{c}-0.029 \\
(0.16)\end{array}$ & $\begin{array}{l}-0.250 \\
(0.79)\end{array}$ & $\begin{array}{l}-1.186 \\
(1.79)\end{array}$ & $\begin{array}{l}-0.412 \\
(1.46)\end{array}$ \\
\hline $\begin{array}{l}\text { Number of } \\
\text { Other } \\
\text { Related or } \\
\text { Unrelated } \\
\text { Individuals }\end{array}$ & $\begin{array}{l}-0.200 \\
(1.10)\end{array}$ & $\begin{array}{l}-0.320 \\
(2.17)\end{array}$ & $\begin{array}{l}-0.253 \\
(1.20)\end{array}$ & $\begin{array}{l}-0.712 \\
(2.51)\end{array}$ & $\begin{array}{c}-0.264 \\
(0.48)\end{array}$ & $\begin{array}{c}-0.344 \\
(1.50)\end{array}$ & $\begin{array}{l}0.075 \\
(0.62)\end{array}$ & $\begin{array}{l}-0.215 \\
(1.04)\end{array}$ & $\begin{array}{l}0.191 \\
(0.82)\end{array}$ & $\begin{array}{l}-0.228 \\
(0.59)\end{array}$ & $\begin{array}{l}-0.684 \\
(1.26)\end{array}$ & $\begin{array}{l}-0.853 \\
(1.41)\end{array}$ \\
\hline $\begin{array}{l}\text { Years Since } \\
\text { Migration } \\
\text { Years Since } \\
\text { Migration } \\
\text { Squared/100 }\end{array}$ & $\begin{array}{c}-0.004 \\
(0.35) \\
\text { (c) }\end{array}$ & $\begin{array}{c}-0.010 \\
(1.32) \\
\text { (c) }\end{array}$ & $\begin{array}{c}-0.063 \\
(3.43) \\
(c)\end{array}$ & $\begin{array}{c}-0.023 \\
(1.11) \\
\text { (c) }\end{array}$ & $\begin{array}{l}0.019 \\
(0.51) \\
(c)\end{array}$ & $\begin{array}{l}0.026 \\
(1.28) \\
(\mathrm{c})\end{array}$ & $\begin{array}{l}-0.114 \\
(1.84) \\
0.325 \\
(1.35)\end{array}$ & $\begin{array}{c}-0.031 \\
(1.35) \\
\text { (c) }\end{array}$ & $\begin{array}{l}0.009 \\
(0.42) \\
(\mathrm{c})\end{array}$ & $\begin{array}{l}0.211 \\
(1.64) \\
-0.817 \\
(1.48)\end{array}$ & $\begin{array}{c}-0.013 \\
(0.25) \\
(\mathrm{c})\end{array}$ & $\begin{array}{c}0.004 \\
(0.11) \\
\text { (c) }\end{array}$ \\
\hline $\begin{array}{l}\text { English Skills } \\
\text { Speak } \\
\text { English Very }\end{array}$ & $\begin{array}{c}\text { peaks En } \\
-1.028 \\
(2.13)\end{array}$ & $\begin{array}{c}\text { at Home } \\
0.150 \\
(0.49)\end{array}$ & $\begin{array}{l}0.108 \\
(0.79)\end{array}$ & $\begin{array}{l}-0.587 \\
(2.31)\end{array}$ & $\begin{array}{l}0.316 \\
(0.66)\end{array}$ & $\begin{array}{l}-0.226 \\
(0.76)\end{array}$ & $\begin{array}{l}-0.184 \\
(0.83)\end{array}$ & $\begin{array}{l}-0.307 \\
(0.61)\end{array}$ & $\begin{array}{l}0.186 \\
(0.64)\end{array}$ & $\begin{array}{c}-0.974 \\
(2.12)\end{array}$ & $\begin{array}{l}1.296 \\
(1.05)\end{array}$ & $\begin{array}{l}0.085 \\
(0.19)\end{array}$ \\
\hline
\end{tabular}




\begin{tabular}{|c|c|c|c|c|c|c|c|c|c|c|c|c|}
\hline \multicolumn{13}{|l|}{ Well } \\
\hline Speak & -0.967 & -13.477 & -0.585 & -1.394 & 0.026 & -0.961 & -1.108 & -0.352 & -1.200 & -1.871 & 1.086 & -0.446 \\
\hline English Well & $(0.80)$ & $(0.04)$ & $(3.00)$ & $(4.67)$ & $(0.04)$ & $(2.85)$ & $(4.83)$ & $(0.70)$ & (3.34) & $(2.14)$ & $(0.92)$ & $(0.89)$ \\
\hline Speak & -11.371 & -13.497 & -1.800 & -1.919 & -14.505 & -2.593 & -2.150 & -1.788 & -0.989 & -12.913 & 0.839 & -0.214 \\
\hline $\begin{array}{l}\text { English Not } \\
\text { Well }\end{array}$ & $(0.03)$ & $(0.02)$ & (3.69) & (3.88) & $(0.02)$ & $(3.28)$ & $(6.61)$ & $(3.20)$ & $(0.97)$ & $(0.02)$ & $(0.60)$ & $(0.28)$ \\
\hline $\begin{array}{l}\text { Speak } \\
\text { English Not } \\
\text { at All }\end{array}$ & 0.000 & 0.000 & $\begin{array}{c}-12.470 \\
(0.03)\end{array}$ & $\begin{array}{c}-14.796 \\
(0.02)\end{array}$ & 0.000 & $\begin{array}{l}-0.465 \\
(0.40)\end{array}$ & $\begin{array}{c}-14.712 \\
(0.03)\end{array}$ & $\begin{array}{l}-2.183 \\
(2.53)\end{array}$ & 0.000 & $\begin{array}{c}-9.918 \\
(0.01)\end{array}$ & $\begin{array}{l}1.436 \\
(0.49)\end{array}$ & $\begin{array}{c}-12.140 \\
(0.01)\end{array}$ \\
\hline Unemployed & $\begin{array}{l}-0.399 \\
(1.34)\end{array}$ & $\begin{array}{l}-0.156 \\
(0.91)\end{array}$ & $\begin{array}{l}-0.019 \\
(0.07)\end{array}$ & $\begin{array}{l}0.174 \\
(0.48)\end{array}$ & $\begin{array}{l}-0.685 \\
(0.90)\end{array}$ & $\begin{array}{l}0.252 \\
(0.76)\end{array}$ & $\begin{array}{l}0.113 \\
(0.44)\end{array}$ & $\begin{array}{l}-0.561 \\
(1.12)\end{array}$ & $\begin{array}{l}0.156 \\
(0.29)\end{array}$ & $\begin{array}{l}-0.775 \\
(0.97)\end{array}$ & $\begin{array}{l}-0.061 \\
(0.04)\end{array}$ & $\begin{array}{l}0.611 \\
(1.04)\end{array}$ \\
\hline $\begin{array}{l}\text { Not in Labor } \\
\text { Force }\end{array}$ & $\begin{array}{l}-0.019 \\
(0.08)\end{array}$ & $\begin{array}{l}-0.010 \\
(0.08)\end{array}$ & $\begin{array}{l}-0.541 \\
(3.06)\end{array}$ & $\begin{array}{l}-0.400 \\
(1.45)\end{array}$ & $\begin{array}{l}-0.669 \\
(1.04)\end{array}$ & $\begin{array}{l}-0.122 \\
(0.48)\end{array}$ & $\begin{array}{l}0.167 \\
(0.75)\end{array}$ & $\begin{array}{l}-0.005 \\
(0.01)\end{array}$ & $\begin{array}{l}-0.461 \\
(1.45)\end{array}$ & $\begin{array}{l}-0.562 \\
(0.86)\end{array}$ & $\begin{array}{l}1.295 \\
(1.63)\end{array}$ & $\begin{array}{l}-0.361 \\
(0.76)\end{array}$ \\
\hline Number of & 0.079 & 0.146 & 0.216 & 0.127 & 0.308 & 0.082 & 0.100 & -0.027 & 0.384 & -0.187 & -0.114 & 0.326 \\
\hline Bedrooms & $(0.88)$ & (2.83) & $(2.62)$ & $(0.96)$ & (1.06) & $(0.62)$ & (1.09) & $(0.19)$ & (2.73) & $(0.93)$ & $(0.32)$ & $(1.48)$ \\
\hline Number of & 0.114 & 0.248 & 0.121 & 0.257 & 0.223 & 0.181 & 0.055 & 0.065 & -0.068 & 0.553 & 0.567 & -0.066 \\
\hline Vehicles & (1.30) & $(4.58)$ & $(1.54)$ & $(2.14)$ & $(0.72)$ & (1.49) & $(0.57)$ & $(0.39)$ & $(0.45)$ & $(2.71)$ & $(1.20)$ & $(0.36)$ \\
\hline$\chi^{2}$ & 123.65 & 506.56 & 550.03 & 328.44 & 49.82 & 187.00 & 469.68 & 204.17 & 107.02 & 84.32 & 66.28 & 70.70 \\
\hline $\begin{array}{l}\text { McFadden } \\
R^{2}\end{array}$ & 0.094 & 0.117 & 0.253 & 0.319 & 0.249 & 0.221 & 0.293 & 0.296 & 0.169 & 0.280 & 0.427 & 0.227 \\
\hline $\begin{array}{l}\text { Prediction } \\
\text { Success }\end{array}$ & 62.4 & 67.1 & 72.4 & 81.3 & 71.6 & 75.0 & 75.5 & 77.6 & 72.0 & 66.1 & 78.0 & 65.8 \\
\hline Sample Size & 948 & 3223 & 1582 & 886 & 162 & 673 & 1157 & 519 & 508 & 221 & 123 & 225 \\
\hline
\end{tabular}

Source: 2001 Census Household Sample File (HSF).

Notes: (a) Asymptotic ' $t$ ' statistics in parentheses.

(b) The birthplaces have been grouped regionally; see Appendix B for detailed listing of countries comprising each regional group.

(c) Variable not entered.

(d) $\mathrm{nz}=$ New Zealand

ukus = Other English Speaking Countries

euro = Europe (except South Eastern Europe, United Kingdom and Ireland)

seeuro $=$ South Eastern Europe

africa $=$ Africa

miden $=$ Middle East and North Africa

seasia $=$ South East Asia

china $=$ China 
sthcent $=$ South and Central Asia

japko $=$ Japan and Korea

pac $=$ Pacific Islands

latam = Latin America 


\section{REFERENCES}

Arabsheibani, G. R., Emami, J. M., and Marin, A. (2004). “The Impact of Computer Use on Earnings in the UK”, Scottish Journal of Political Economy, Vol. 51, No. 1, pp. 82-94.

Australian Bureau of Statistics (2003). Technical Paper: Census of Population and Housing Household Sample File Australia 2001, Catalogue No. 2037.0, Australian Bureau of Statistics, Canberra.

Baker, M.. and Benjamin, D. (1994). "The Performance of Immigrants in the Canadian Labor Market", Journal of Labor Economics, Vol. 12, No. 3, pp. 369-405.

Borghans, L., and Weel, B. (2004). "Are Computer Skills the new Basic Skills? The Returns to Computer, Writing and Math Skills in Britain”, Labour Economics, Vol. 11, No. 1, pp. 85-98.

Chiswick, B. R. (1977). “Sons of Immigarnts: Are They at an Earnings Disadvantage?”, American Economic Review, Vol. 67, No. 1, pp. 376-80.

Chiswick, B. R. (1978). “The Effect of Americanization on the Earnings of Foreign-born Men”, Journal of Political Economy, Vol. 86, No. 5, pp.897-922.

Chiswick, B. R., and Miller, P. W. (1985). "Immigrant Generation and Income in Australia”, Economic Record, Vol. 4, No. 2, pp. 168-92.

Chiswick, B. R., and Miller, P. W. (1995). “The Endogeneity Between Language and Earnings: An International Analysis”, Journal of Labor Economics, Vol. 13, No. 2, pp. 246-88.

Chiswick, B. R., and Miller, P. W. (1998). "The Economic Cost to Native-Born Americans of Limited English language Proficiency”, Report Prepared for the Center for Equal Opportunity, available www.ceousa.org/earnings.html

Chiswick, B. R., and Miller, P. W. (2003). "The Complementarity of Language and Other Human Capital: Immigrant Earnings in Canada”, Economics of Education Review, Vol. 22, pp. 469-80.

Chiswick, B. R., and Miller, P. W. (2005a). "Why is the Payoff to Schooling Lower for the Foreign Born?”, photocopied, Business School, The University of Western Australia.

Chiswick, B.R. and Miller, P.W. (2005b) “Linguistic Distance/A Quantitative Measure of the Distance Between English and Other Languages”, Journal of Multilingual and Multicultural Development. 26(1) 2005 pp.1-11. 
Daldy, B., and Gibson, J. (2003). "Have Computers Chnaged the New Zealand Wage Structure? Evidence from Data on Training?”, New Zealand Journal of Industrial Relations, Vol. 28, No. 1, pp. 13-21.

DiNardo, J. E., and Pischke, J. (1997). "The Returns of Computer Use Revisited: Have Pencils Changed the Wage Structure Too?”, The Quarterly Journal of Economics, Vol. 112, No. 1, pp. 291-303.

Dolton, P., and Makepeace, G. (2004). "Computer Use and Earnings in Britain”, The Economic Journal, Vol. 114, March, pp. C117-C129.

Dustmann, C. and van Soest. A. (2001). "Language Fluency and Earnings: Estimation with Misclassified Language Indicators," Review of Economics and Statistics, Vol. 83, No. 4, pp. 663-674.

Fry, R. and Lowell, B. L. (2003), "The Value of Bilingualism in the US Labor Market”, Industrial and Labor Relations Review, Vol. 57, No. 1, pp. 128-40.

Goss, E.P., and Phillips, J. M. (2002). "How Information Technology Affects Wages: Evidence Using Internet Usage As a Proxy for IT Skills", Journal of Labor Research, Vol. 23, No. 3, pp.463-74.

Halvorsen, R., and Palmquist, R. (1980). "The Interpretation of Dummy Variables in Semilogarithmic Equations”, American Economic Review, Vol. 70, No. 3, pp. 474-75.

Hildreth, A. K. G. (2001). “A New Voice or a Waste of Time? Wage Premiums from Using Computers for Communication in the UK Workplace”, British Journal of Industrial Relations, Vol. 39, No. 2, pp. 257-84.

Krueger, A. B. (1993). "How Computers Have Changed the Wage Structure: Evidence from Microdata, 1984-1989”, The Quarterly Journal of Economics, Vol. 108, No. 1, pp.33-60.

Liu, J. T., Tsou, M. W., and Hammitt, J. K. (2004). “Computer Use and Wages: Evidence from Taiwan”, Economics Letters, Vol. 82, No. 1, pp. 43-51.

Miller, P. W., and Mulvey, C. (1997a). “Computer Skills and Wages”, Australian Economic Papers, Vol. 36, No. 68, pp.106-13.

Miller, P. W., and Mulvey, C. (1997b). "Computer Usage Among Australia Workers”, Australian Journal of Labour Economics, Vol. 1, No. 1, pp. 25-47.

Miller, P. W., and Neo, L. M. (2003). "Labour Market Flexibility and Immigrant Adjustment”, Economic Record, Vol. 79, No. 246, pp. 336-56. 
Voon, M. D., and Miller, P. W. (2005). "Undereducation and Overeducation in the Australian Labour Market”, Economic Record, forthcoming. 